DOI 10.15393/j10.art.2018.3641

Константин Абрекович Баршт

доктор филологических наук, профессор, ведущий научный сотрудник

Отдела новой русской титературы

Института русской литературы (Пушкинский Дом) РАН

(Российская Федераиия, Санкт-Петербург)

konstantin_barsht@pushdom.ru

\title{
Калдиграфическое письмо Ф. М. Достоевского в рукописях к роману «Преступление и Наказание»
}

Аннотация. В статье проанализированы каллиграфические записи из подготовительных материалов к роману Ф. М. Достоевского «Преступление и Наказание», находящихся в трех записных тетрадях (РГАЛИ. Ф. 212.1.3-5). Автор исследования выдвигает концепцию, согласно которой все языки, с помощью которых писатель фиксировал информацию в своем творческом процессе, в том числе и выработанный Достоевским язык идеографической записи, требуют нового подхода, не делающего различий между вербальными и идеографическими языками в рукописи писателя. Каллиграфические записи, сделанные писателем во время работы, фиксируют новые имена, понятия и события, отсутствующие в печатных текстах Достоевского и доселе остаются малоизученными и невостребованными, являясь при этом важными источниками информации об истории создания его произведений. Данная статья восполняет пробел, образованный невниманием публикаторов текстов Достоевского к его идеографическим записям, обнаруживающимся в рукописях к роману «Преступление и Наказание» и составляющим единое информационно-семантическое целое со всеми остальными записями в его тетрадях 1864-1866 гг.

Ключевые слова: Ф. М. Достоевский, текстология, каллиграфия, «Преступление и Наказание», творческий процесс, экфрасис, невербальный язык

$\mathrm{O}$ том, что рукописи Ф. М. Достоевского - это не только вербальные записи и что тексты записных тетрадей Достоевского не всегда умещаются в типографский набор привычной для нас «публикации рукописей», говорилось еще сто лет назад ${ }^{1}$. Очевидно также, что проблема публикации рукописей писателя как единого целого, включая записи на всех языках, входящих в его творческий инструментарий, связана с другими разделами достоеведения: изучением его сюжета и поэтического языка, генезисом нарративных форм, вопросами экфрасиса и предметного мира писателя и др. Нами уже выражалась уверенность в том, что «лишь учет всех особенностей, всех элементов рукописей Достоевского позволит на основе черновых материалов более глубоко изучить и обосновать (психологически) приемы его творчества» [Баршт, Тороп, 1983: 140] ${ }^{2}$, и в последнее время видны сдвиги в этом направлении. Современные исследования и публикации все большее внимание обращают на идеографию писателя как необходимый и перспективный ресурс науки и литературы.

() К. А. Баршт, 2018 
К настоящему моменту проведена большая работа по исследованию идеографических языков рукописей Достоевского, предпринята попытка создания графико-словесной модели рукописного наследия Достоевского (рукописи к роману «Преступление и Наказание») [Баршт, 1999], создан ряд описаний идеографии писателя как феномена его литературного творчества ${ }^{3}$.

Как известно, в издании рукописей Ф. М. Достоевского в составе Полного собрания сочинений (ИРЛИ РАН, 1972-1990) был применен принцип, согласно которому лишь один из информационных слоев текста был признан необходимым для воспроизведения - вербальные записи. Рукописи в издании были аналитически расчленены по хронологическому принципу, в рамках которого к каждому из произведений Достоевского был привязан определенный набор избранных текстов «тетрадей», а идеография, включая каллиграфию, оказалась за пределами публикации. В настоящее время идет переосмысление этого принципа, исходя из того, что рисунки, сделанные писателем в процессе его творческой работы, отнюдь не всегда «боковая ветвь творчества», вопреки авторитетному мнению А. Эфроса [Эфрос: 18], но находятся непосредственно на пути выработки писателем художественной формы [Баршт, 2000]. В новом Полном собрании сочинений писателя, работа над которым идет в Пушкинском Доме, рисунки и каллиграфия писателя учитываются и комментируются. Одновременно становится все более ясно, что обычные «типографско-шрифтовые» издания рукописей писателя далеко не полностью удовлетворяют тем требованиям, которые выдвигаются сегодня в филологической науке.

Важно понять, что в формировании текстового значения страницы рукописи Достоевского участвуют все находящиеся на ней знаки, включая и те, к которым трудно подобрать аналоги и соответствия. Описывая текст черновой записи писателя в виде обычного вербального «документа жизни и творчества», в категориях прошедшего и совершенного времени, мы существенно облегчаем себе исследовательскую задачу, но недопустимо сужаем научный ресурс изучаемого материала. Новые ресурсы и возможности откроют для исследователей такие издания, в которых будут учтены все наличные знаки, присутствующие в рукописи Достоевского. В таком случае сама рукопись будет прочитываться как внутренний диалог писателя с собой в акте творческой автокоммуникации. Потому для полноты картины необходим такой способ издания, в котором было бы возможно сохранить ценную информацию, зафиксированную в идеографических текстах. Для адекватного воспроизведения этого материала придется отказаться от царствующей ныне издательско-текстологической модели, где во внимание принимаются лишь те знаки, которые сводимы к графемам кириллического или латинского алфавитов. Первые шаги в этом направлении уже сделаны ${ }^{4}$.

Идеография Достоевского, как получивший графическое выражение процесс творческой автокоммуникации, имеет специфическую природу. Исходной точкой творческого процесса является рефлексия, где означающими 
могут быть названы лишь биоэлектрические импульсы мозга, интерпретировать которые пока что не представляется возможным. Никакого «рассказывания» в акте «внутренней речи», при погружении в свои личные впечатления, быть не может, внутренняя речь есть молчаливая речь, в этом ее «основное отличие» [Выготский: 285]. Наррация означает нарушение этого принципиального молчания и выработку внешней бытийной точки, способной стать опорой в акте самовыражения личности как свидетельствовании о своем бытии.

Способ связи между «внутренней» и «внешней» речью, свойственный тому или иному писателю, адекватно отображается в формате самых первых записей, сделанных им в процессе работы над произведением. Посредством целой группы вербальных и идеографических языков происходит перевод значений внезнакового «внутреннего» языка на язык знаков, обладающих планом выражения; при переходе информации в формат словесного выражения образовывается пространство, населенное набором языков, оперирующих мотивированными знаками, - возникает идеографическое письмо. Одна из функций идеографии Достоевского - пауза в переходе цельного суггестивного знака в дискретно-фрактальную условную форму. Возникновение разных форм обращения личного «я» к другим адресатам, включая и несобственно-прямую речь, и всевозможные «описания», связано с многоканальными переводами выработанных в этом процессе значений с языка внутренней речи на принципиально иной природы язык речи внешней. В процессе работы писателя отношение автокоммуникации к коммуникации меняется стадиально, и в качестве главной переходной ступени здесь выступает перевод иконически мотивированного знака в состояние условного словесного, при максимально возможном сохранении исходного качества референции, что, конечно, невозможно в полной мере. Такого рода перевод всегда меняет значение, и для того, чтобы, по возможности, уберечь первоначальный смысл, появляется экфрасис как способ сохранения утраченной цельности образа. Начиная творческий процесс с мышления на внезнаковом языке внутренней речи, с помощью иконически мотивированных знаков, идеограмм, писатель приходит на новом уровне к, казалось бы, пройденной и утраченной цельности смысла, реализуя ее затем в художественной форме своего произведения.

Продуктивность идеографического письма основана на том, что в результате активного взаимоотношения между разными языками и текстами в пределах двух каналов связи, автокоммуникации и коммуникации, в записной тетради Достоевского генерируются новые смыслы. Как отмечает Ю. М. Лотман, в такого рода коммуникативной ситуации возникает феномен «"качания” структур»: «...тексты, создаваемые в системе “Я-Он”, функционируют как автокоммуникации и наоборот: тексты становятся кодами, коды - сообщениями» [Лотман: 175]. Текст, созданный в синтетическом единстве нескольких языков, обретает новые смыслы на основе синтагматической переорганизации текста, новые значения образуются с помощью 
символов, индексов и эмблем, «за счет втягивания в сообщение внетекстовых ассоциаций разных уровней - от наиболее общих до предельно личных» [Лотман: 171]. Знак проходит ряд мутаций по направлению «иконический условный», получая многообразные выражения на странице записной тетради и стимулируя своим семантическим динамизмом творческий процесс художника. Мнемонико-идеографические записи в рукописях Достоевского предваряют и подготавливают форматы косвенного рассказа и форм несобственно-прямой речи, которые мы встречаем в окружающих рисунки конспективных словесных набросках. Значения элементов мира, каким он представлен автору, меняются при изменении уровня иконической мотивированности языка; инструментом, который позволял Достоевскому осуществлять этот перевод от «моего» видения к «его» (актора) личному видению, был процесс сдвига формата денотанта от предметно-мотивированного рисунка (например, портрета) к дальнейшему снижению уровня иконичности образа вплоть до каллиграфической записи и, далее - к «конспективной» черновой записи, с помощью лексем естественного языка, фактической реализации художественной формы в ее первоначальном виде.

В оценке каллиграфии как одного из начальных этапов устно-письменной автокоммуникации Достоевского следует исходить из возможности видеть в ее особенностях генетическое начало творческих приемов писателя, так как некоторые особенности письменной речи существуют в устной форме до их придумывания и применения на письме ${ }^{5}$. Диалог между различными точками зрения на мир, сформированный в художественном произведении, является своего рода отражением процессов автокоммуникативного диалога в творческом процессе писателя: возникновения нарратива из мифосимволической исходной позиции - «внутренней речи» автора о себе и о мире. Далее автор формирует такой способ записи, который оказывается в состоянии примирить внешний естественный язык культуры и его внутреннюю речь, взаимно непереводимые, однако находящие консенсус в зоне их столкновения в наборе из нескольких идеографических кодов. При соприкосновении нескольких текстов на разных языках, сосуществующих в составе одного дискурса, происходит семиотический взрыв, смещение точки видения, что порождает рассказывание некой истории и формирует тем самым повествовательный дискурс.

В семиозисе творческого процесса Достоевского содержатся закономерности, которые ведут к пониманию основных свойств повествования в его произведениях, и особую роль в этом процессе играла «каллиграфия». Подобно тому, как живописец долго размешивает краски, ища нужный оттенок для одного-единственного мазка, Достоевский подолгу прописывал имена разных исторических деятелей, вдумываясь в основное бытийное назначение их жизненного пути («Юлий Цезарь», «Марк Аврелий», «Наполеон Бонапарт», «Гарибальди», «Петр І»), философов, писателей, художников («Мальбранш», «Гюго», «Жермен <де Сталь>», «Рафаэль», «Жорж Санд», 
«Писемский» и др.), богословов («Василий Великий», «Иоанн Златоуст», «Григорий Богослов»), названия географических пунктов («Ореноко», «Итон», «Семипалатинск», «Севастополь», «Пиринеи» ${ }^{* *}$ «Москва», «Петербург» и др.), имена персонажей произведений мировой литературы («Коробочка», «Коломбина», «Кирсанов», «Мадазима»), имена персонажей своих произведений («Птицын», «Вельчанинов», «Катенька», «Ганечка», «Свидригайлов», «Дуня», «Картузов»), характеристики персонажей («Прирожденный сплетник», «Князь Христос», «Герой не он, а мальчик», «Характеры»), названия своих произведений («Идиот», «Житие великого грешника»), важнейшие повороты сюжета («У матери», «Особое прибавление», «Минута», «Убийство»), изменения в формате повествования («От себя», «Вся идея», «Дневник», «Финал»), ключевые элементы развития сюжета («Последняя борьба», «Последнее Memento», «Где живут Алеша и Иван», «Хронология», «Идея», «К нему», «Окончательный план романа» и др.), ища нужный коннотирующий смысл.

Обратимся к рукописям к роману «Преступление и Наказание» и попробуем увидеть, что дает для уточнения истории создания этого произведения прочтение каллиграфических прописей, содержащихся в этих текстах.

\footnotetext{
* Так у Достоевского.

** Так у Достоевского.
} 


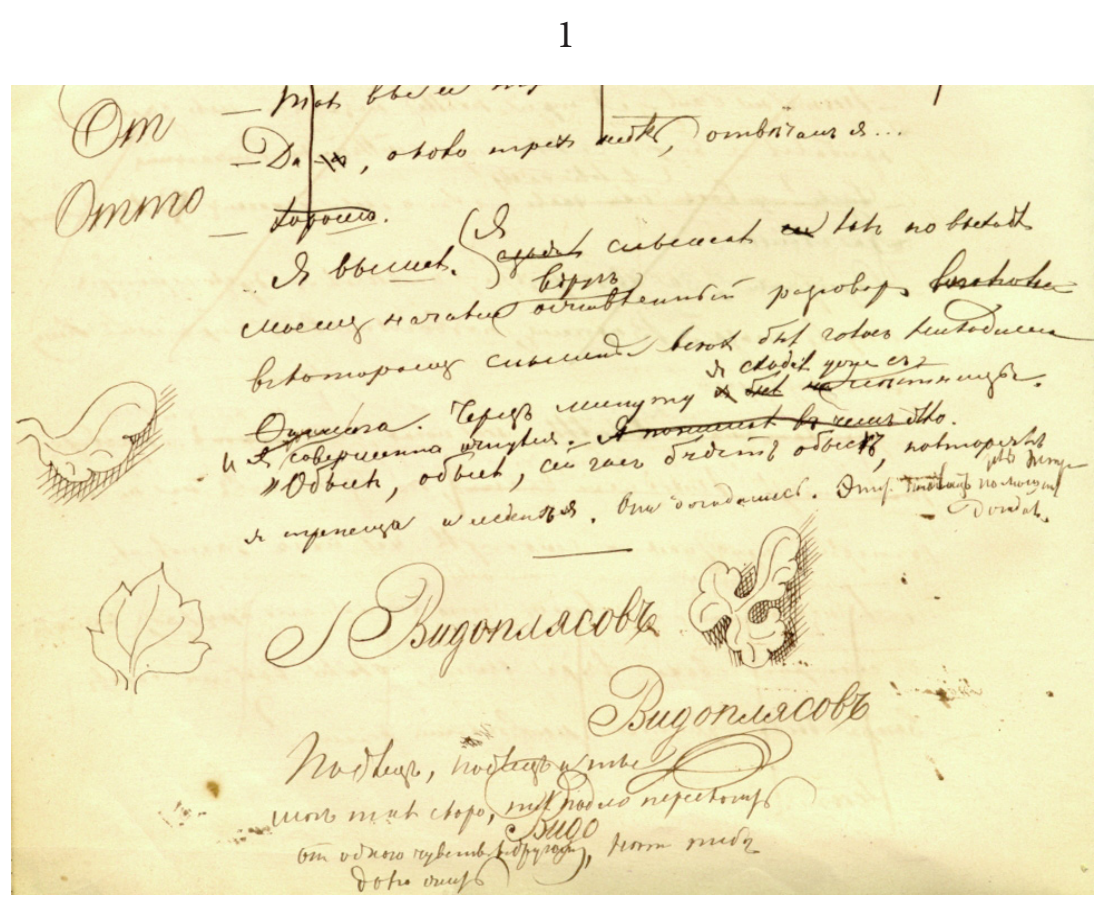

Илл. 1. РГАЛИ. Ф. 212.1.4. С. 68

Возможны два варианта интерпретации каллиграфических записей «От», «Ommo», размещенных на полях слева. Посещая Ревель, Достоевский мог слышать о скандальной истории барона Отто Рейнгольда Людвига фон УнгернШтернберга (1744-1811). Утонченный ревельский аристократ, он тем не менее активно занимался пиратством в Финском заливе, за что в конечном итоге был арестован и сослан в Сибирь. Такого рода «неистовые» характеры особенно интересовали писателя в период создания романов «Преступление и Наказание» и «Идиот». Отмечая ряд каллиграфических прописей Достоевского, фиксирующих имена римских императоров «Caius Caligula, Claudius, Nero, Galba, Vittellius, Vespasianus» (РГАЛИ. Ф. 212.1.6. С. 106), Б. Н. Тихомиров обнаруживает в этом ряду запись «Otto», трактуя ее как ошибочное написание имени императора Отона (ram. Otho). Ранее такой вариант написания имени императора Отона поставлен в связь с записью «Данилов, Ott» (РГАЛИ. Ф. 212.1.5. С. 10) ${ }^{6}$. Отсюда можно предположить, что эту запись также «допустимо интерпретировать как недописанное имя Ott<0> (тем более что между Нероном и Отоном существовали сложные личные отношения)» [Тихомиров: 12].

«Видо», «Видоплясов» (2 р.) - пропись, расположенная в нижней части страницы, не случайно оформлена в виде подписи с росчерком, этот персонаж повести Достоевского «Село Степанчиково и его обитатели» был крайне недоволен своей фамилией и пытался изменить ее на более благородную с помощью многократных попыток сформировать подпись «Уланов», вероятно, с таким же затейливым росчерком ${ }^{7}$. 


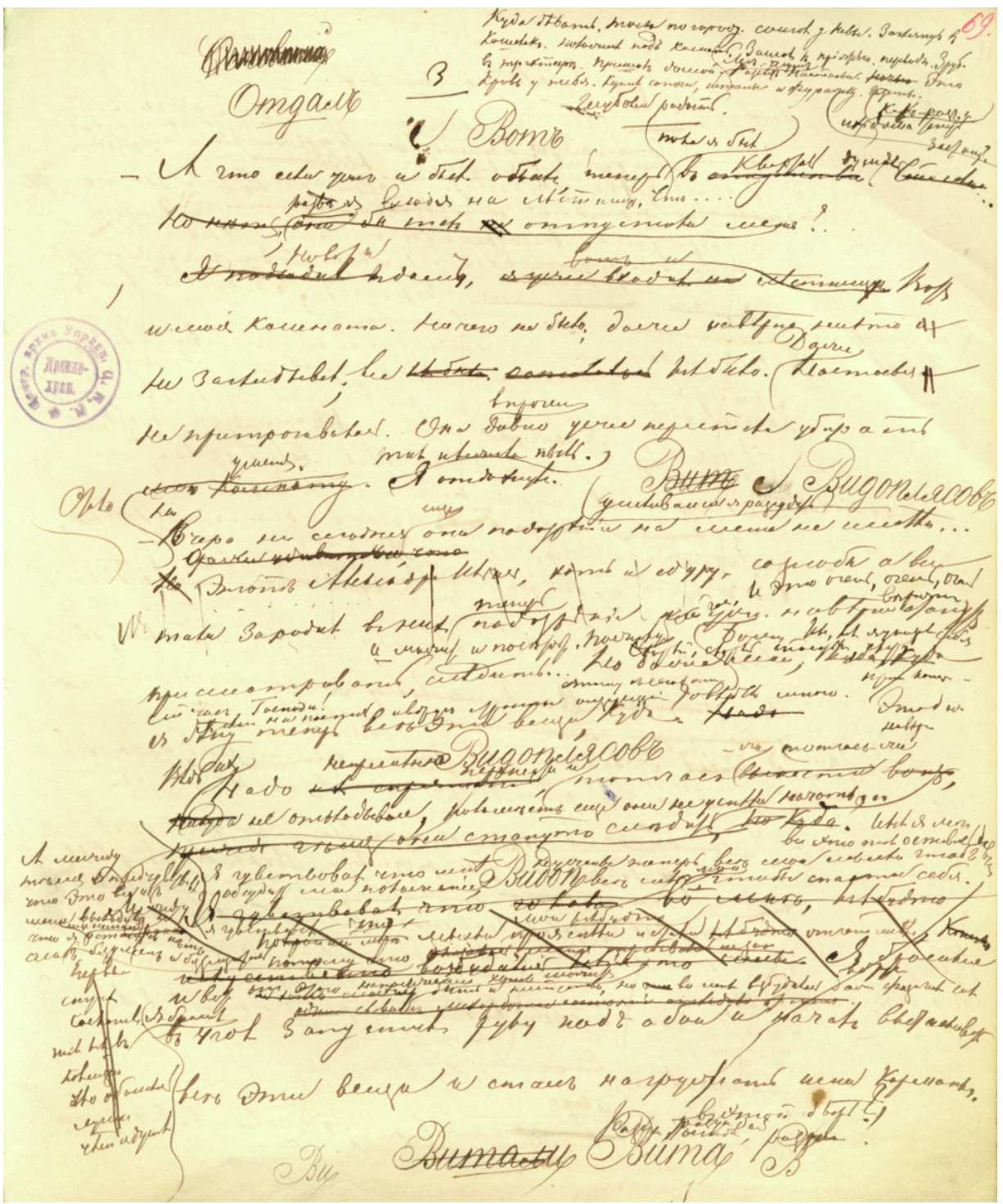

Илл. 2. РГАЛИ. Ф. 212.1.4. С. 69

Зачеркнутая запись внизу страницы «Витали» (а также пробы пера «Вита», «В», «Ви» внизу страницы и зачеркнутая запись «Вит» в середине), вероятно, имеет отношение к Ивану Петровичу Витали (1794-1855), профессору скульптуры Академии художеств, автору известных скульптурных портретов А. С. Пушкина и Н. В. Гоголя, а также барельефов Исаакиевского собора в Санкт-Петербурге. 


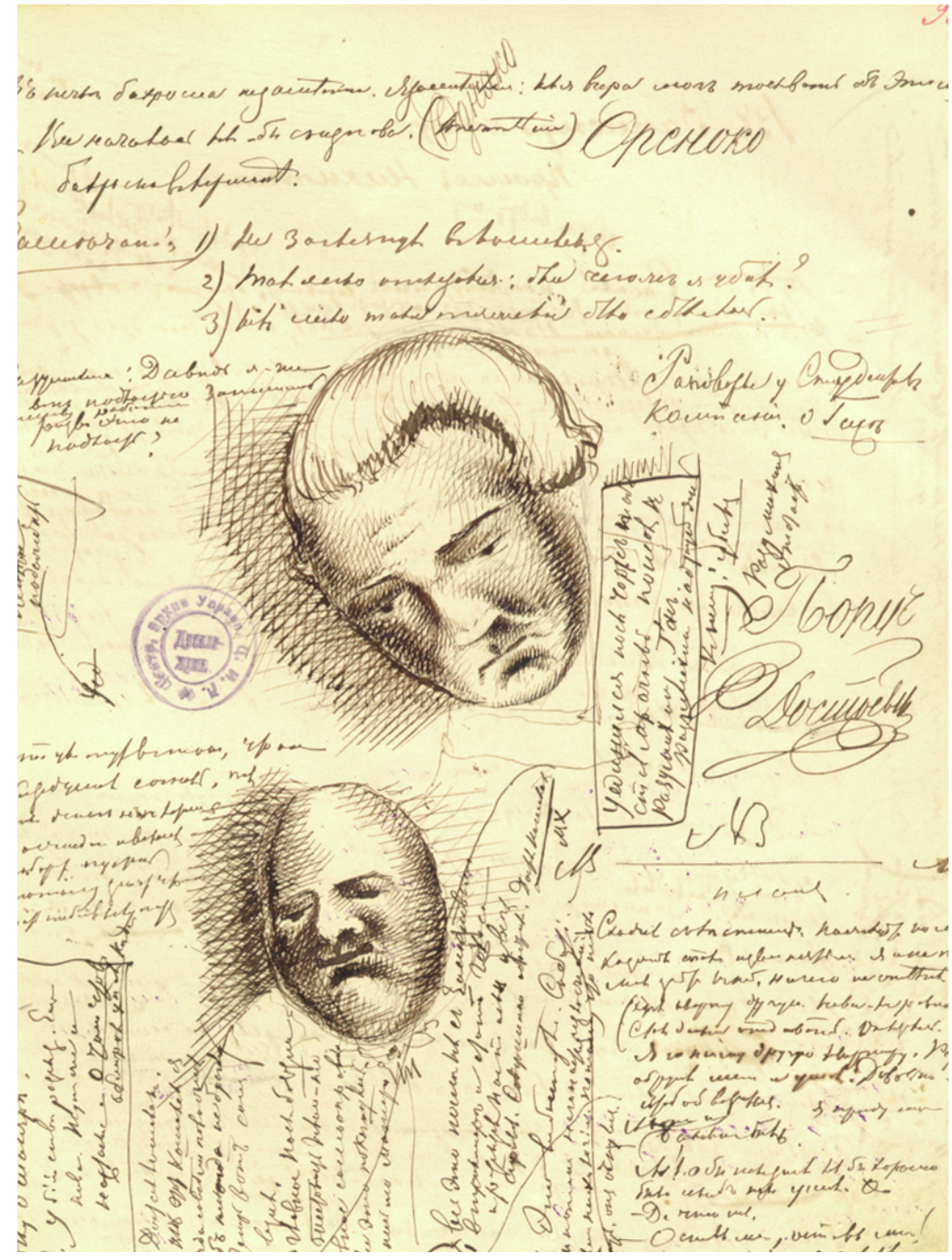

Илл. 3. РГАЛИ. Ф. 212.1.4. С. 95

Запись «Поруи. Достоевск<ий>», оформленная в виде подписи, завершающейся росчерком, имеет автобиографический характер. В 23 года, в возрасте Родиона Раскольникова, будущий писатель имел чин инженерного подпоручика и, выйдя в отставку 19 октября 1844 г., получил чин следующего ранга, инженер-поручика, с прибавлением: «в отставке» ${ }^{8}$. Запись связана с решением вопроса о дальнейшем развитии сюжета романа, где решающую роль играет литературный дебют Раскольникова, в котором 
он обосновывает свой протест против унизительной социальной роли, предлагаемой ему обществом. Работая над этим эпизодом, писатель вспоминал свой литературный дебют, в котором важное значение имел отказ от государственной службы.

«Ореноко» - запись вверху страницы, связанная с устойчивым интересом Достоевского к истории открытия Америки, личности и деяниям Христофора Колумба, а также к роману Даниэля Дефо «Робинзон Крузо». Южноамериканский след в творчестве Достоевского весьма значителен ${ }^{9}$. Южная Америка не раз упоминается в «Дневнике Писателя» (напр.: 21; 465 и 24; 478); мотив владения всей Бразильской Империей встречается в «Ряде статей о русской литературе» $(18 ; 231)$, в «Селе Степанчикове» упоминается Кайенна, столица Французской Гвианы, расположенная чуть южнее острова, на котором жил Робинзон Крузо (3; 85). Среди подготовительных записей к роману «Преступление и Наказание» мы встречаем еще один южноамериканский след - упоминание коренных жителей Центральной Америки ацтеков $(7 ; 124)$. Робинзон Крузо в романе Даниэля Дефо проводит годы на необитаемом острове в Атлантическом океане, в районе дельты реки Ориноко. Первое полное издание 1-го тома «Робинзона» на русском языке, в переводе Корсакова ${ }^{10}$, стало заметным явлением в русской литературной жизни, об этом издании позитивно отозвался В. Г. Белинский, назвав его источником «чистейшего и упоительнейшего наслаждения» [Белинский: 37]. Имя героя книги Дефо было одним из устойчивых знаков культурной памяти Достоевского: оно обнаруживается в журнальной версии рассказа «Чужая жена» (1848), в письме Достоевского к брату Михаилу от 3 ноября 1957 г. $(28$; 289); находясь на каторге, писатель мысленно сравнивал с Робинзоном Крузо одного из заключенных, описав это впоследствии в романе «Записки из Мертвого Дома» $(4 ; 174)$. Стоит также вспомнить, что в раннем детстве, находясь в деревне Даровое, будущий писатель любил играть в «индейцев» вместе со своими братьями и крестьянскими детьми. Мысль о том, чтобы скрыться в Америке, приходит на ум Раскольникову, который не знает, куда девать себя в своем социальном и моральном «запустении» («Зачем приводил его Разумихин?.. - бормотал он в бессилии, садясь опять на диван. - Что ж это? Бред ли это все со мной продолжается или взаправду? Кажется, взаправду... А, вспомнил: бежать! скорее бежать, непременно, непременно бежать! Да... а куда? <...> Лучше совсем бежать... далеко... в Америку, и наплевать на них!» (6; 99-100). В стремлении найти себя и свое «счастье» думает о бегстве в Америку Свидригайлов $(6 ; 215)$ и советует сделать то же Раскольникову. В автографе «повести» «После сна» упоминается некое место в Южном полушарии, откуда герой прибыл после тридцати пяти лет отсутствия $(7 ; 40)$ - срок, сопоставимый с нахождением Робинзона на острове возле реки Ориноко. Возможно, «робинзонада» была одним из вариантов решения дальнейшей судьбы Раскольникова в этот период работы над романом «Преступление и Наказание». 


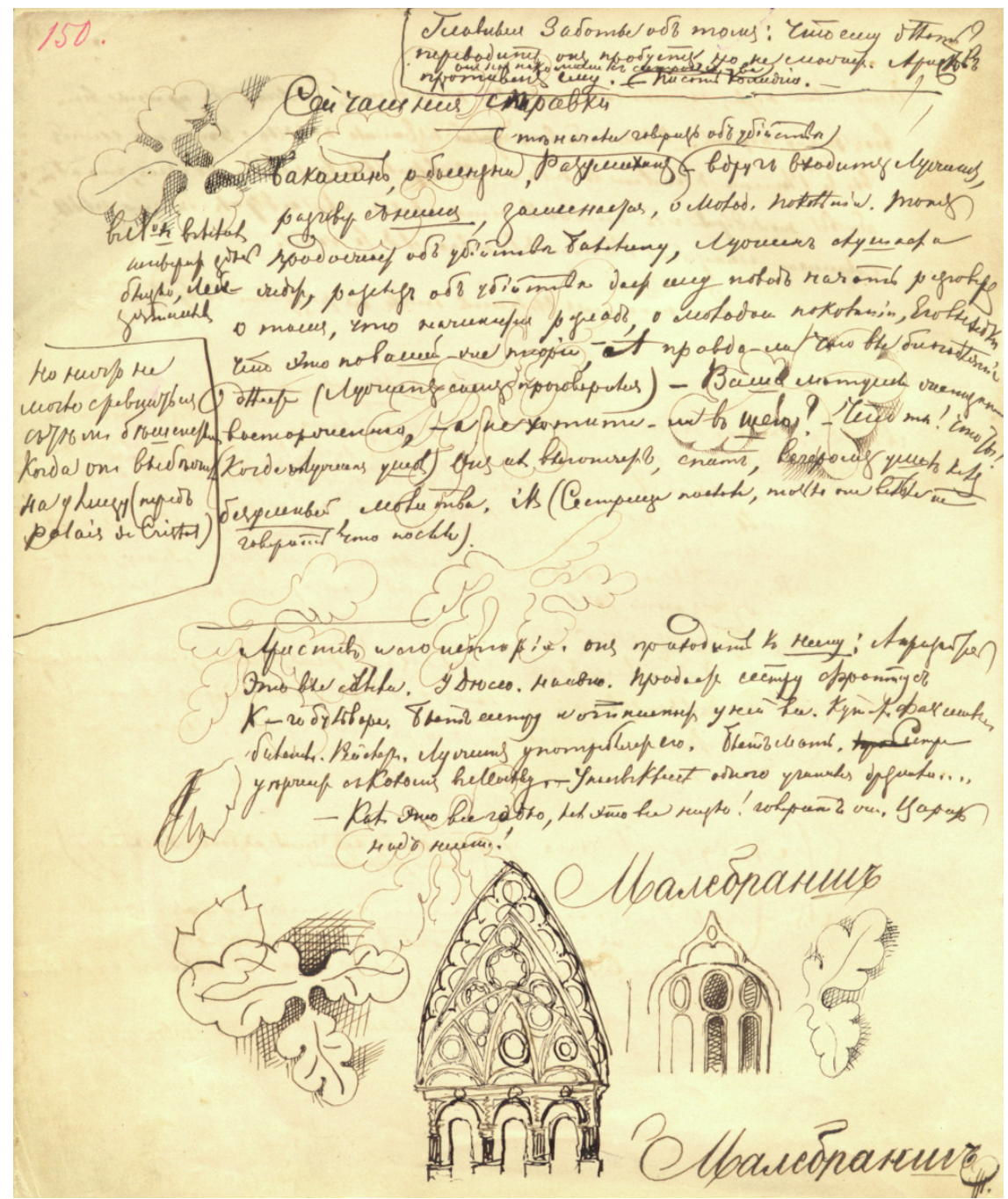

Илл. 4. РГАЛИ. Ф. 212.1.4. С. 150

Запись «Малебранш» (2 р.) обозначает думы Достоевского о философии Николя Мальбранша (Nicolas Malebranche; 1638-1715), выдающегося французского философа, ученика Р. Декарта, основоположника окказионализма. Его монументальный труд «Разыскания истины» (Malebranche N. «De la recherche de la vérité», 1674-1675) на протяжении XVIII и XIX вв. был существенным компонентом европейской философской жизни, оказывал значительное влияние на русскую литературу (см.: [Бочаров: 213]). Достоевский мог читать эту книгу лишь в оригинале, так как первый перевод на русский язык состоялся в начале следующего столетия (СПб., 1903-1906) ${ }^{11}$. 


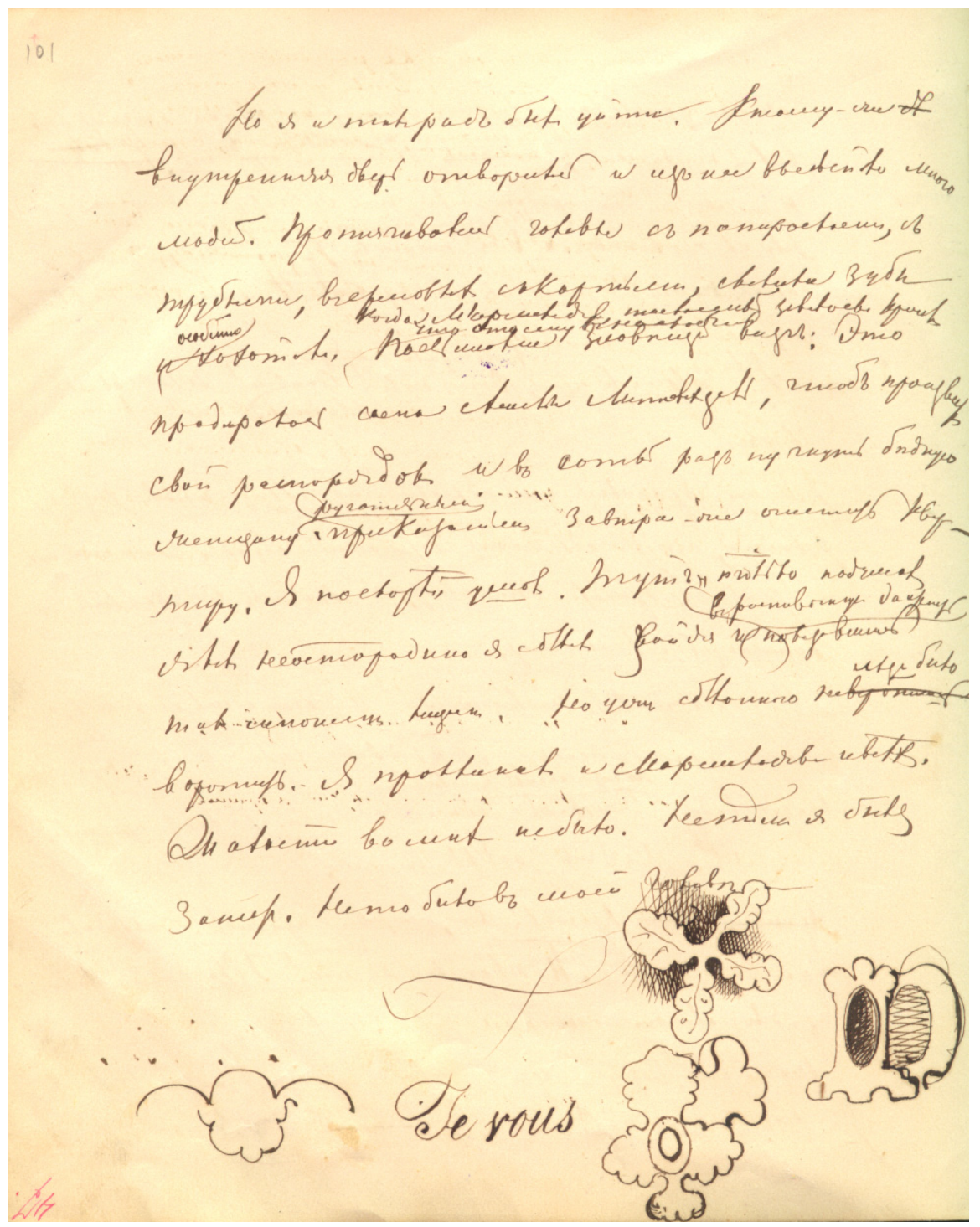

Илл. 5. РГАЛИ. Ф. 212.1.3. С. 101 (47)

«Je vous» - незавершенная каллиграфическая пропись на французском языке, фиксирующая модальность намерения: «Я вас (Я вам)». Эта запись сделана после заключительной фразы автографа первой версии романа «Преступления и Наказания», повести «Под судом»: «Жалости во мне не было. Не тем я был занят. Не то было в моей голове» (7; 108). 


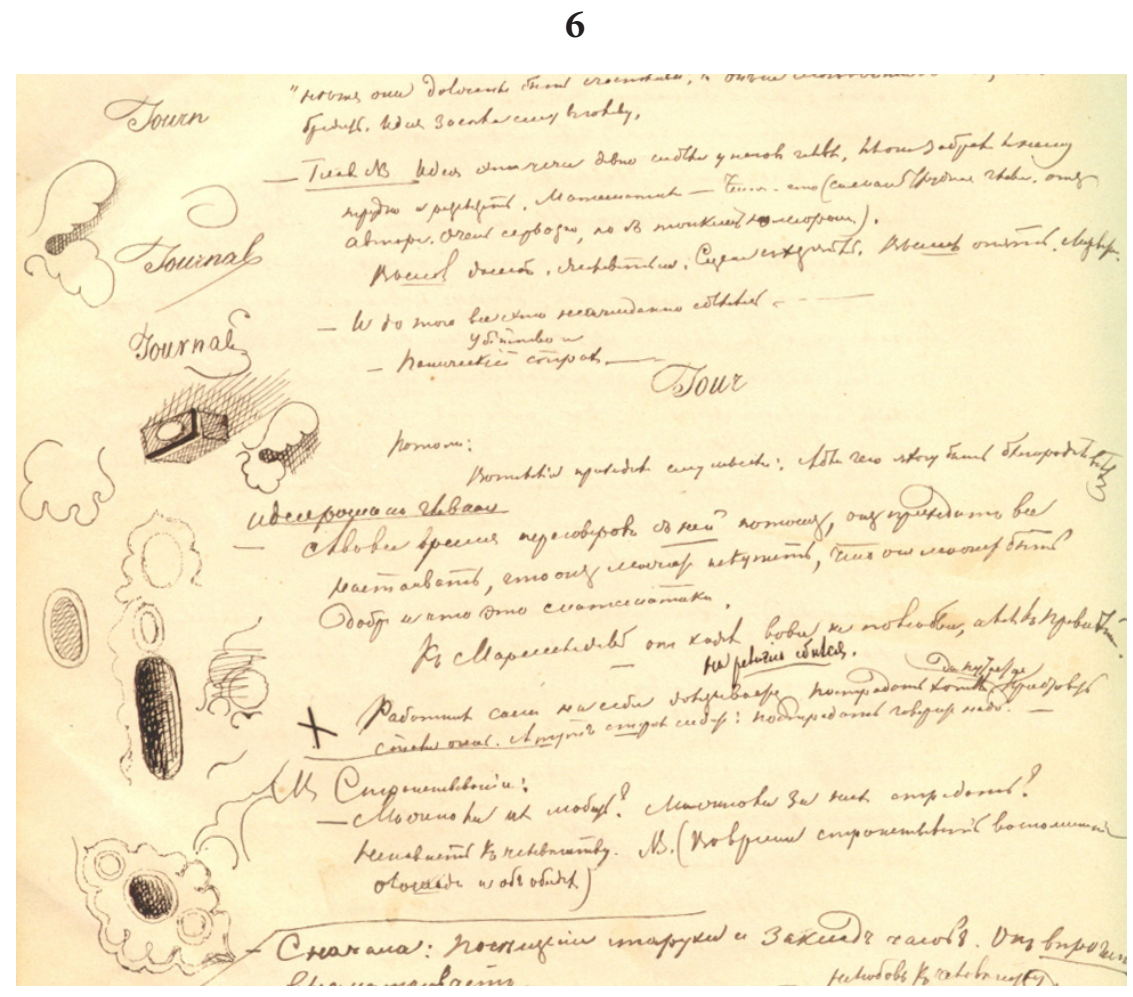

Илл. 6. РГАЛИ. 212.1.3. С. 109 (39)

Каллиграфические прописи: «Jour», «Journ», «Journal» (2 p.; «Дневник» $\oint p$.) - связаны с размышлениями Достоевского о нарративном формате произведения, в процессе его переработки переходящего из повести («После сна»), написанной от первого лица в виде дневника, в роман с недиегетическим повествователем. Смена повествовательного формата сопровождалась записями на данной странице: «Рассказ от имени автора, как бы невидимого, но всеведущего существа, но не оставляя его ни на минуту, даже с словами: “и до того всё это нечаянно сделалось”» $(7 ; 146)$ - и на странице 107 (41): «Рассказ от себя, а не от него. Если же исповедь, то уж слишком до последней крайности, надо всё уяснять. Чтоб каждое мгновение рассказа всё было ясно» (7; 148). Окончив свои каллиграфические размышления о «журнале» и утвердившись в новом формате нарратора, Достоевский формирует фабульный план: «Сначала: посещение старухи и заклад часов. Он, впрочем, высматривает. Потом письмо, бульвары, неприятности, нелюбовь к человечеству и вдруг идея о старухе, не то чтобы совсем нечаянно, ибо надо признаться, что она была давно, но теперь она в первый раз сложилась в форме полной и отчетливой. Затем, и уже совершенно нечаянно, - Лизавета. Тут переворот и муки. И затем вдруг исполнение и панический страх» (РГАЛИ. Ф. 212.1.3. С. 109 (39). Ср.: 7; 147). Этому же вопросу о форме повествования посвящена запись на странице 120: «Если в форме Дневника». (РГАЛИ. Ф. 212.1.3. С. 120 (28); ср.: 7; 141). 


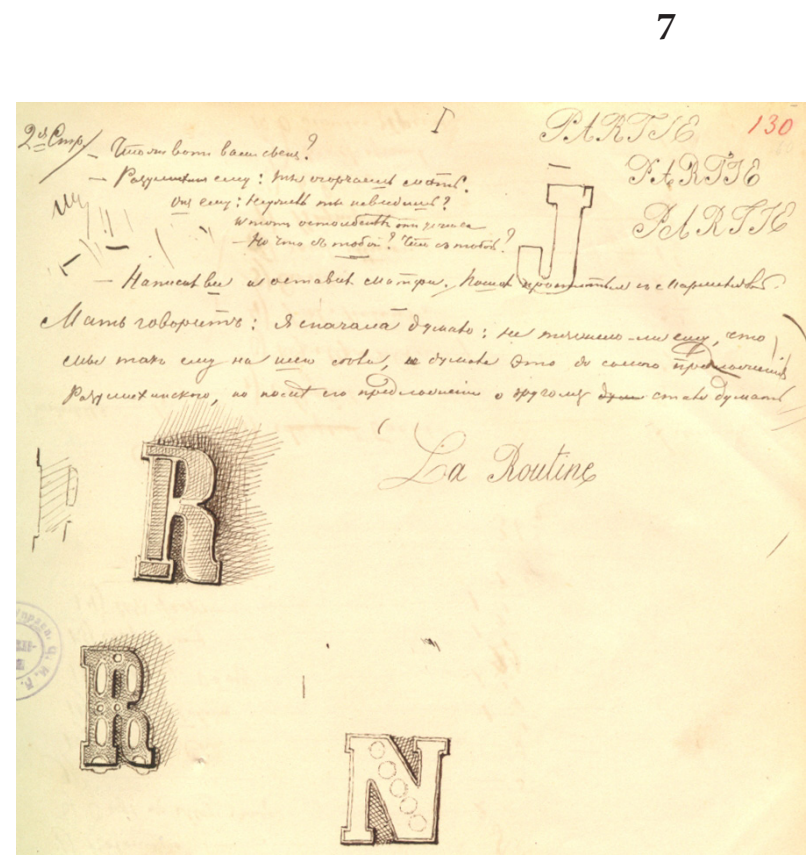

Илл. 7. РГАЛИ. Ф. 212.1.3. С. 130 (18)

«La Routine» (3 р.) - пропись и декорированные буквы «R» $(2 \mathrm{p}$.$) и «N», составляющие$ слово, связаны с размышлениями писателя об основном пункте доктрины Раскольникова относительно существования двух типов людей, один из которых должен строго следовать установленным правилам и олицетворяет собой «рутину» в виде возможности стать "семьянином, отцом, мужем, хорошим гражданином и проч.» $(7 ; 136)$, в то время как второй имеет право на свободный выбор в осуществлении своих намерений. Записи на смежных страницах тетради показывают, что фактор "рутины» трактован писателем как основная опасность для его героя-философа, отождествляющего «рутину» и «толпу» и комментирующего это сочетание словом «низость» $(7 ; 89)$. Писатель намечал возможность ввести в сюжет романа разговор о рутине, которая, по мнению его героя, необходимо потребует от человека, имеющего душу и сердце, пойти на преступление (7; 94), о том, что в «ужасном положении», в котором оказываются люди, «слушаться судьбы нельзя, о рутине и проч.» $(7 ; 142)$. В конце концов, Достоевский утверждается в своей мысли о том, что этот разговор «о рутине», убивающей человека как свободное и мыслящее существо, состоится между Раскольниковым и Порфирием Петровичем, где будет окончательно выяснена суть теории Раскольникова: «У Порфирия. Познакомились. Разговор, о чем спорили на вечере. Выпытывает мысли. Раскольников догадывается, в ударе. О работнике. О разных предметах. О преступлении, о власти рутины и исключения и проч.» $(7 ; 170)$. В дальнейших записях Достоевский подчеркивал важность этого разговора «насчет рутины и избранных» (7; 173). Записи на странице сопровождаются изображением декорированных букв «R» и «N», входящих в слово «Routine».

Объемная буква «Ј», расположенная в верхней правой части страницы, вероятно, является началом слова «Journal» (см. № 6; комм. к с. 107).

«PARTIE» (3 р.) - составленное из прописных букв слово, вероятно, связано с мыслью о противостоянии указанных двух групп людей, имеющих, согласно концепции Раскольникова, различные возможности в осуществлении своих прав. 


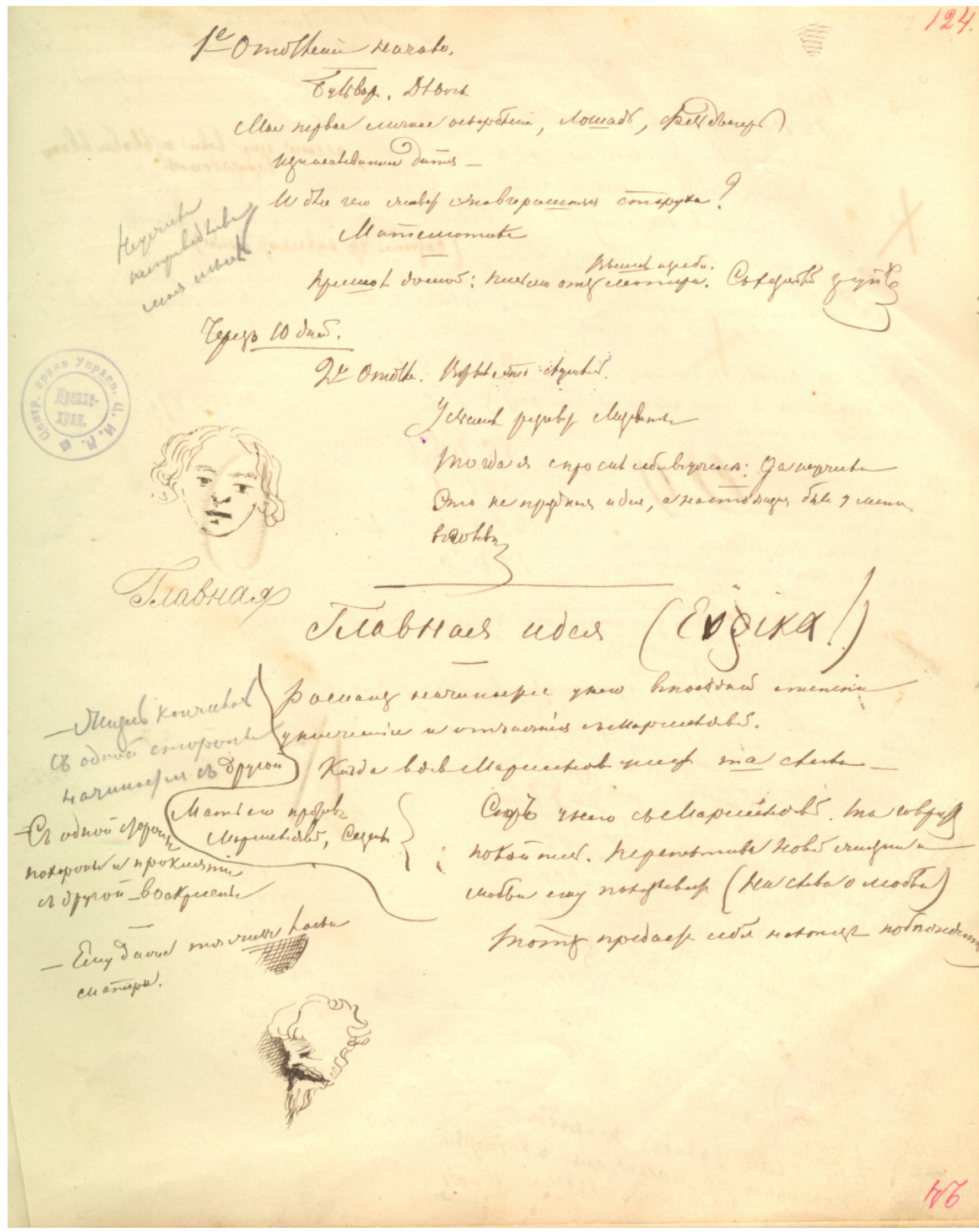

Илл. 8. РГАЛИ. Ф. 212.1.3. С. 124 (24)

Пропись «Главная» в левой части страницы связана с заголовками фрагментов сюжета «Преступления и Наказания»: «Главная идея» и «Еvрєка» фиксирующими основную сюжетную коллизию «Преступления и Наказания»: «Спор у него с Мармеладовой. Та говорит: покайтесь. <...> Перспективы новой жизни и любви ему показывает. <...> С одной стороны похороны и проклятие, с другой - воскресение» $(7 ; 138)$. 
9

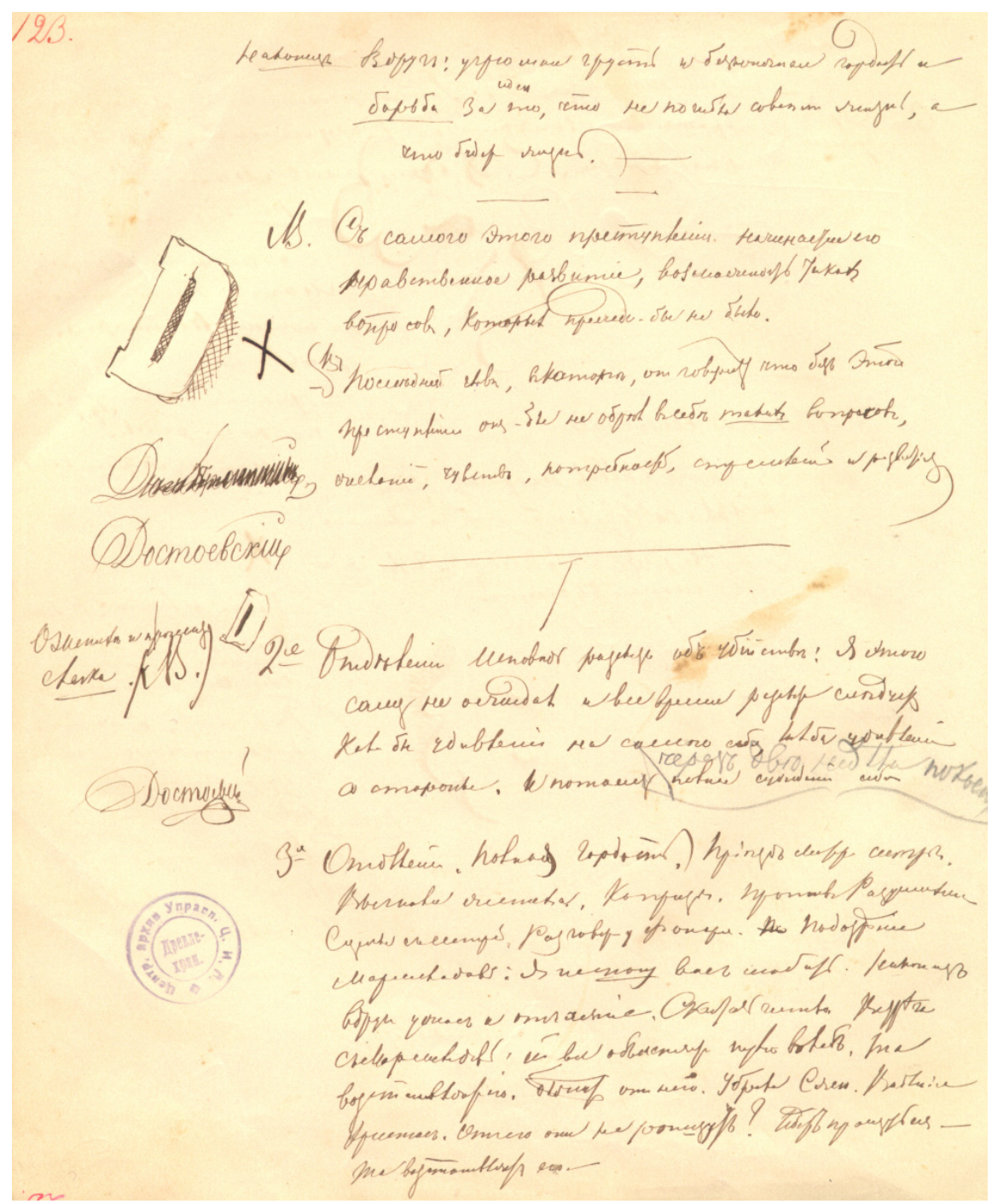

Илл. 9. РГАЛИ. Ф. 212.1.3. С. 123 (25)

Подпись с росчерком «Достоевский» (3 р., из них - 1 р. зачерк.), заглавная буква «Д» (2 р.) появились после окончания записи наброска, фиксирующего тяжкие моральные переживания Раскольникова на каторге, запись, вероятно, имеет автобиографический характер: «Наконец. Вдруг: угрюмая грусть и бесконечная гордость и борьба за то, что не погибла совсем жизнь, а что будет жизнь. <...> В последней главе, в каторге, он говорит, что без этого преступления он бы не обрел в себе таких вопросов, желаний, чувств, потребностей, стремлений и развития» $(7 ; 140)$. 


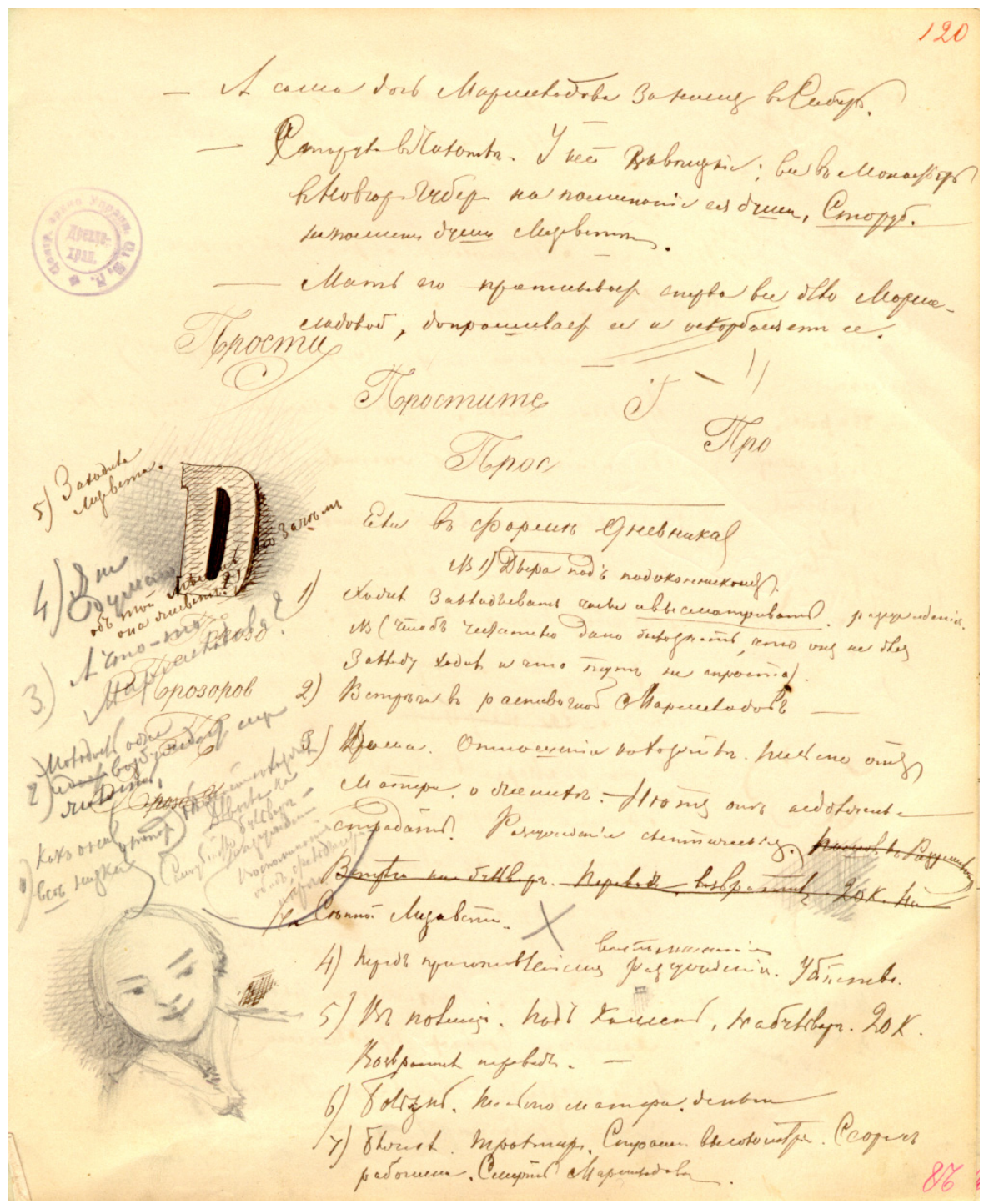

Илл. 10. РГАЛИ. Ф. 212.1.3. С. 120 (28)

Записи «Про», «Прост», «Простите», «Прости<тутка>» (?) в середине листа, выше портретного рисунка, изображающего молодую девушку, предположительно - Соню Мармеладову, сделаны после завершения формирования сюжетного хода, связанного с ее «оскорблением» со стороны Пульхерии Александровны Раскольниковой, заподозрившей ее в соучастии в преступлении: «Мать его приписывает сперва все дело Мармеладовой, допрашивает ее и оскорбляет ее» $(7 ; 141)^{13}$. 


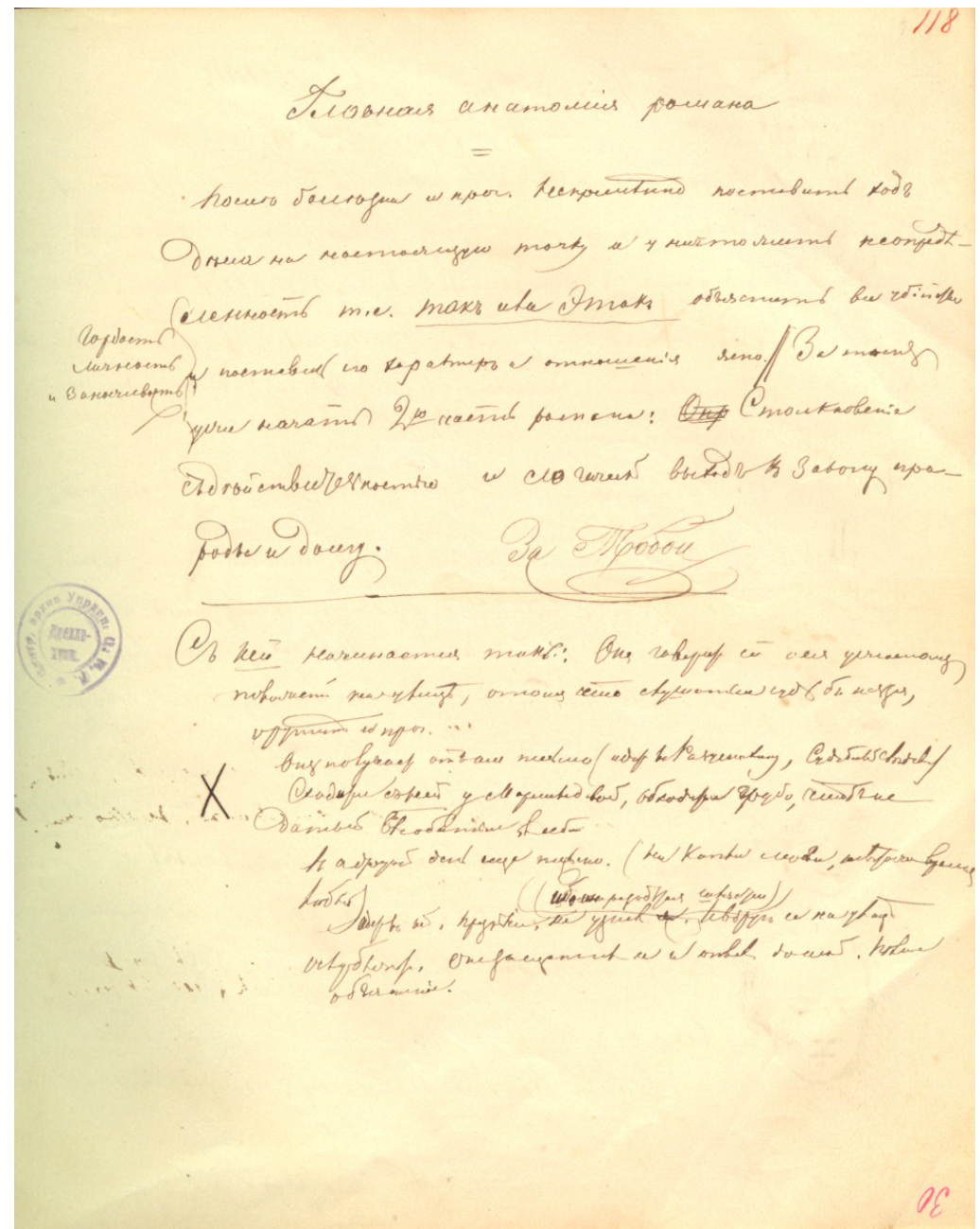

Илл. 11. РГАЛИ. Ф. 212.1. 3. С. 118 (30)

Пропись «За Пробой» в середине страницы: это определение содержится в нескольких записях в рукописях к роману: «Вот ему и проба» (РГАЛИ. Ф. 212.1.5. С. 123; ср.: 7; 190), «Вот и проба ему будет» $(7 ; 254)$. Речь идет о разведывательном визите Раскольникова к процентщице с целью провести репетицию преступления (6; 5-11). Судя по этой записи, «проба» как сюжетное событие, составляющее основу первой части романа, возникло в творческих планах Достоевского в период подготовки им «второй» редакции романа поздней осенью 1865 г.: «Сперва: Ходил, например, к старухе высматривать, а между тем легкомысленно и сам почти еще не верит себе, что сделает. Так, на всякий случай» (РГАЛИ. Ф. 212.1.3. С. 122; ср.: 7; 139). 


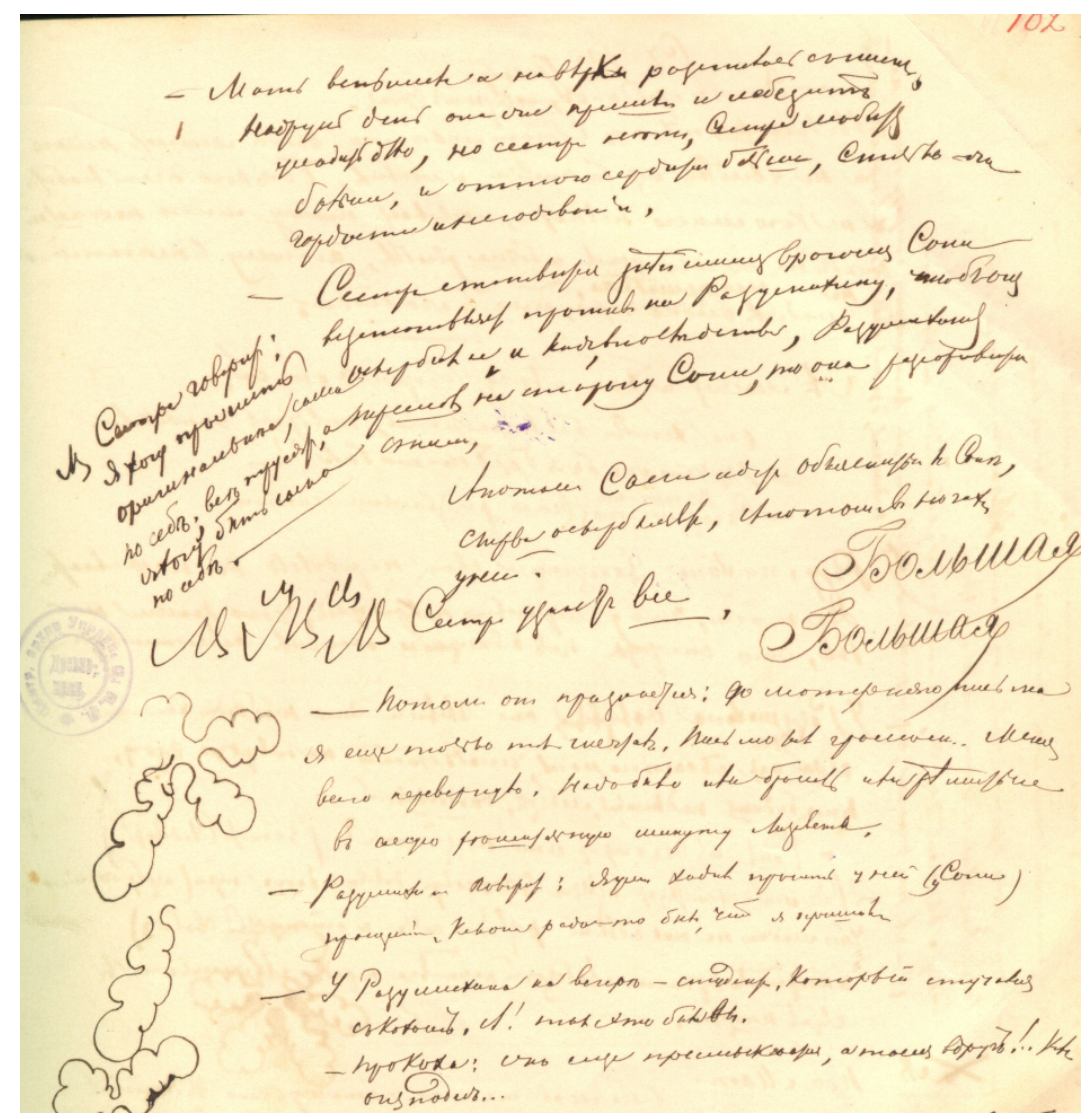

Илл. 12. РГАЛИ. Ф. 212.1.3. С. 102 (46)

Запись «Большая» (2 р.) в правой части страницы, вероятно, относится к требованию Сони Мармеладовой, обращенному к Раскольникову: прийти с повинной и «донести на себя», зафиксированному на странице 105 «третьей записной книжки» (РГАЛИ. Ф. 212.1.5. С. 105): «Когда он открыл всё Соне, он отнюдь не сказал ей: не говори никому. Ее поражает эта мысль: значит, высоко ее чтит. Ей же как бы легче. Он говорит Соне: “Меня ищут”. Та пугается. - “Как же ты сейчас только умоляла меня донести на себя?” Отвечает: “Лучше донести самому. Есть разница”. - “Какая?” - “Большая”» $(7 ; 178)$. На данной странице содержится ряд записей, связанных с формированием мысли Раскольникова о совершении преступления: «Потом он признается: до матернего письма я еще только мечтал. Письмо как громом... Меня всего перевернуло. Надо было или бросить, или решиться, в самую решительную минуту - Лизавета. <..> NB. Под конец романа рождается у иных мысль, что он помешался на том, что убил старуху. Разумихин верит этому и разуверяет Соню. Это Заметов сообщает ему мысль» $(7 ; 150)$. 


\section{3}

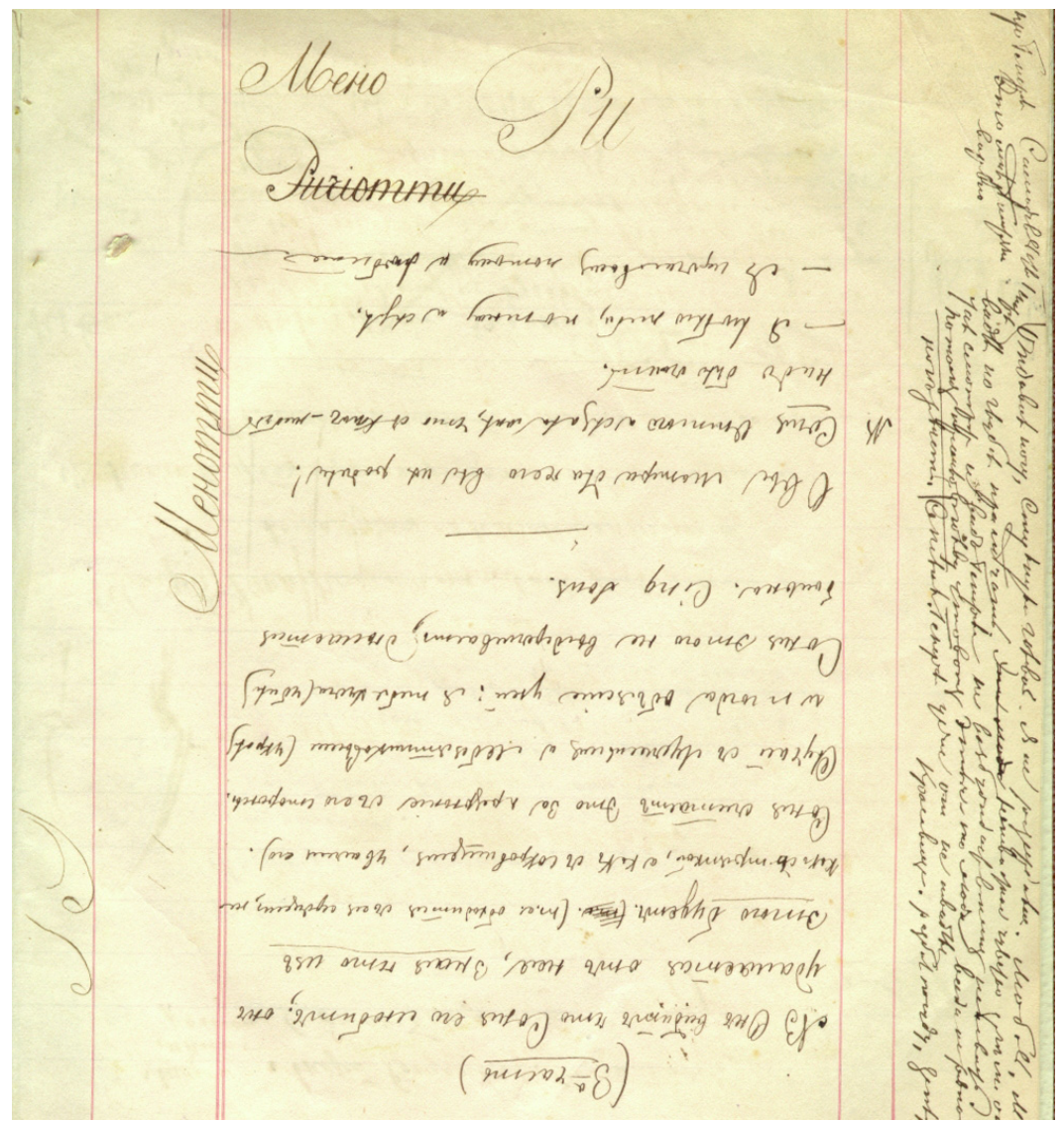

Илл. 13. РГАЛИ. Ф. 212.1.5. С. 2

Прописи «Ри», «Ричиотти» (зачерк.), «Мено», «Менотти» фиксируют имена сыновей и сподвижников Джузеппе Гарибальди в борьбе за освобождение Италии от иноземного господства и объединения страны: Риччотти Гарибальди (um. Ricciotti Garibaldi; 1847-1924) и Доменико Менотти Гарибальди (um. Domenico Menotti Garibaldi; 1840-1903). Менотти был участником в походах Гарибальди 1859, 1860, 1862, 1866-1867 и 1870 гг., названный так его отцом в честь итальянского революционера, карбонария Чино Менотти (1798-1831), 3 февраля 1831 г. поднявшего восстание в Модене. Заговорщики были разгромлены, а сам Менотти казнен. Его имя стало нарицательным, обозначая героя-мученика, павшего за объединение Италии. «Моено» (вероятно, искаженное «Modena») - место действия описанных выше событий. С конца 1850-х гг. военные действия в Италии и связанные с этим политические события были в центре внимания русской литературы и публицистики. 
14

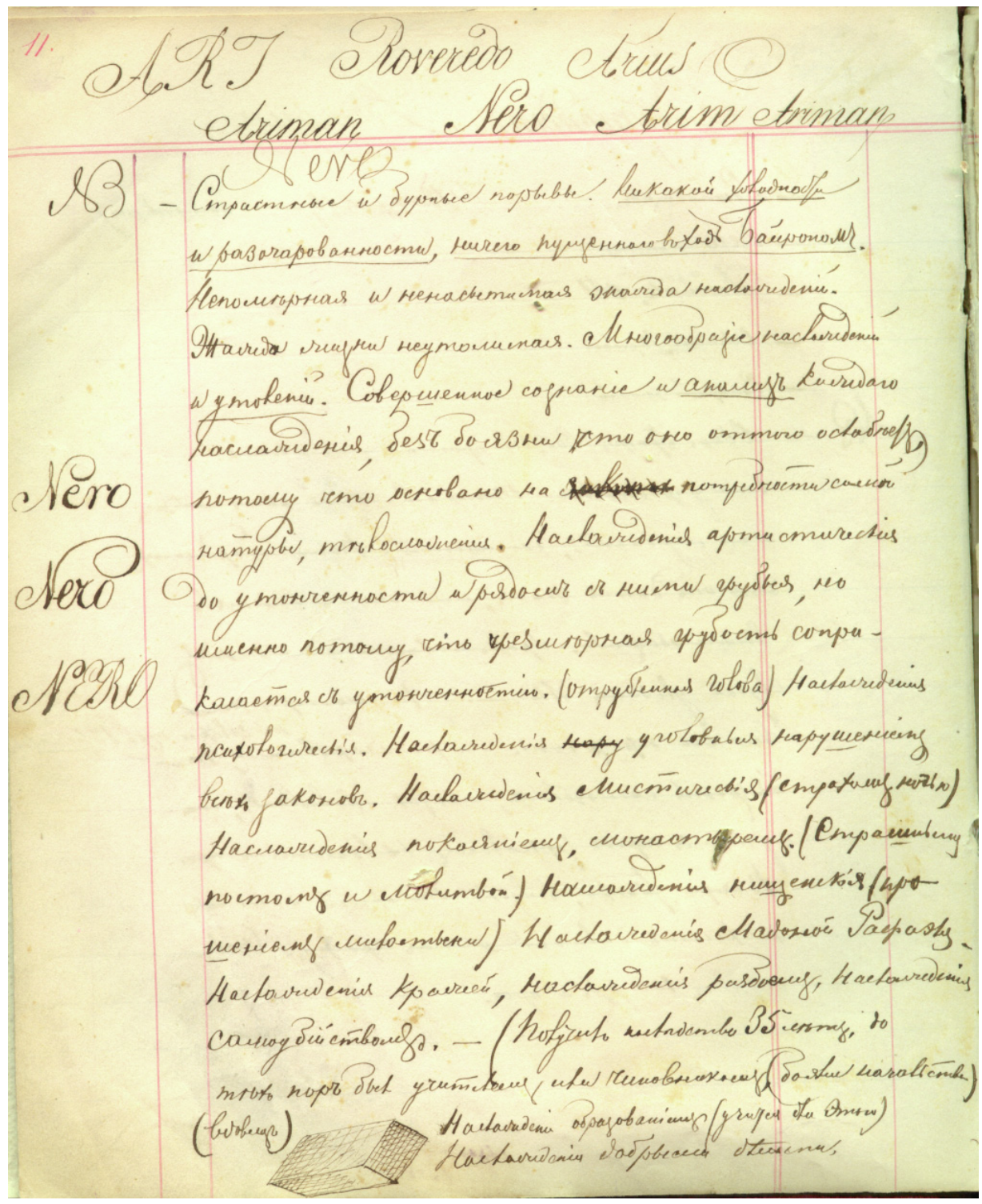

Илл. 14. РГАЛИ. Ф. 212.1.5. С. 11

Ряд каллиграфических прописей из древней истории. «Nero» (3 p. слева и 2 р. вверху страницы) - римский император Нерон (Claudius Caesar Nero; 37-68 н. э.), черты его характера были использованы Достоевским при строительстве образа персонажа, одержимого «страстными и бурными порывами». 
«Arim», "Ariman» (2 p.) (дp.-nepc. Ahriya mainyus) - в религии зороастризма обозначал силы тьмы и зла; с его образом связываются катастрофы, неурожаи, природные катаклизмы, болезни и смерть. Это имя Достоевский мог обнаружить в поэме Дж. Г. Байрона «Манфред», где Ариман появляется в своем «чертоге», на троне - огненном шаре, окруженном духами. Это произведение многократно переводилось и издавалось на русском языке ${ }^{14}$. О зороастрийском боге зла Достоевский мог также слышать от Феликса Густавовича Толля (1823-1867), его однокашника по Главному инженерному училищу, после его окончания - преподавателя этого учебного заведения, который активно изучал и популяризировал архаические языческие верования. В своих воспоминаниях А. И. Савельев, ротный офицер Главного инженерного училища, свидетельствует, что на своих лекциях Толль «говорил юношам о таких предметах (о настоящей, истинной религии, буддизме и даосизме, коммунизме и равенстве и пр.), о которых им не приходилось ни читать, ни слышать» [Ф. М. Достоевский в воспоминаниях современников: 169].

Запись «Arius» возможно связана с лекцией Ф. И. Толля о происхождении религии, которую он 11 марта 1849 г. прочел на заседании кружка Петрашевского, в том числе и об арианской модели христианства, объявленной ересью Никейским (325 г.) и Константинопольским соборами (381 г.). Арий (256-336) выступал с идеей земного Иисуса Христа, бытие которого связано временем, в то время как, по его представлениям, вечен лишь Бог-Отец; сочинения Ария были уничтожены поколениями борцов с его концепциями, а его самого отлучили от Церкви за идею о созданности Иисуса Христа Богом-Отцом и даже сущностной противоположности Ему. Задумывая роман о христоподобном «положительно прекрасном человеке», приближающемся к идеалу Христа, Достоевский мог принимать во внимание идеи арианства, тем более, что был хорошо знаком с творениями Григория Богослова.

«Roveredo" - возможно, запись связана с победой над австрийскими войсками при взятии Ровередо, одержанной Наполеоном в 1796 г. 


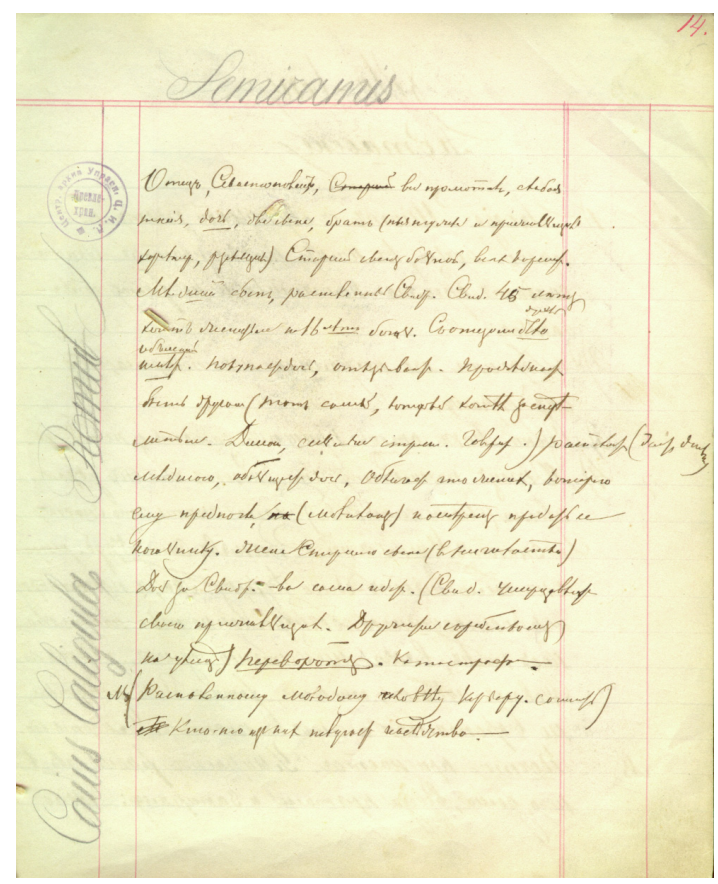

Илл. 15. РГАЛИ. Ф. 212.1.5. С. 14

«Semiramis» - главная героиня одноименной трагедии Вольтера («Семирамида»; 1748). Владелица одного из семи чудес света, «висячих садов», вавилонская царица Семирамида (Шаммурат; IX в. до н. э.) обладала огромной властью и богатством, но вошла в историю как несчастный человек, получивший жестокое возмездие за свое коварство. Ее историю положил Вольтер в основу фабулы одноименной пьесы. Стоит также отметить, что «Семирамидой Севера» называл Екатерину II Вольтер: «Sémiramis du Nord, auguste impératrice» ${ }^{15}$, и это словосочетание в XIX в. обратилось в шаблонный комплиментарный титул, используемый для обозначения умной и деятельной женщины. В круге возможных аллюзивных связей «прописи» Достоевского афоризм хорошо известного ему Козьмы Пруткова: «Умная женщина подобна Семирамиде» ${ }^{16}$. Судя по краткой записке, адресованной А. У. Порецкому в январе 1847 г. $^{17}$, Достоевский собирался посетить бенефис одного из актеров итальянской оперной труппы, гастролировавшей в Петербурге и, возможно, намеревался слушать арии из опер, среди которых могла быть и «Семирамида» Дж. Россини, либретто которой было написано по мотивам трагедии Вольтера ${ }^{18}$.

«Caius Caligula» - римский император Гай Юлий Цезарь, по прозвищу Калигула (Gaius Julius Caesar Caligula; 12-41н. э.), символ жестокого и деспотичного правителя. Достоевский знакомился с жизнеописаниями Нерона и Юлия Цезаря по лекциям Т. Н. Грановского, опубликованным в изложении историка И. К. Бабста (1824-1881) в журнале «Время» ${ }^{19}$.

«Romul<us $>$ » (?) - вероятно, персонаж римской истории Ромул (Romulus), убивший своего брата-близнеца Рема (Remus). Согласно мифу, братья были детьми весталки Реи Сильвии и бога Марса и основателями Рима, вскормленные волчицей. Тит Ливий свидетельствует, что Ромул был первым царем Древнего Рима (753-716 гг. до н. э.). 
16

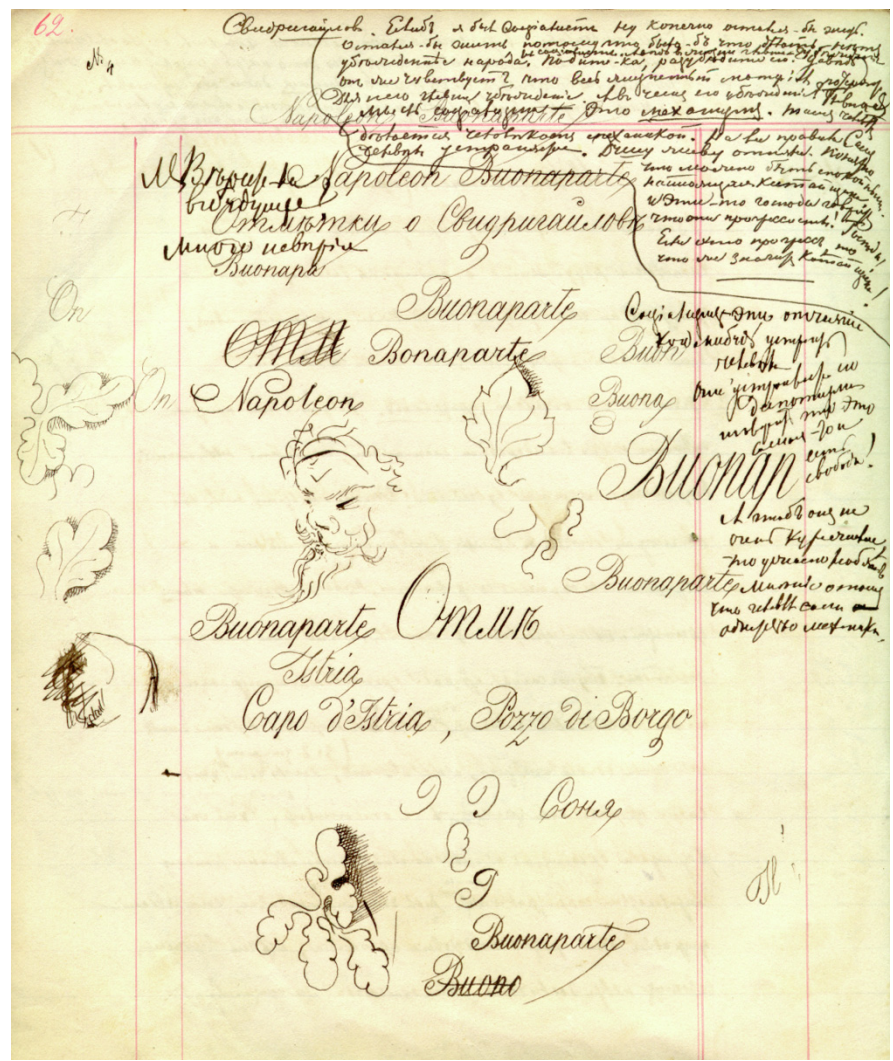

Илл. 16. РГАЛИ. Ф. 212.1.5. С. 62
Многократно повторенная пропись «Napoleon Buonaparte», сопровождаемая карикатурным изображением Наполеона III Шарля Луи Наполеона Бонапарта (Charles Louis Napoléon Bonaparte, 1808-1873), президента Французской республики с 1848 по 1852 г., а далее императора по 4 сентября 1870 г.

"Capo d'Istria» вероятно, граф Иоанн Каподистрия (1776-1831), русский политический деятель, ставший первым президентом независимой Греции. Он занимал министерские должности в правительстве Республики Ионийских островов (1803-1809), затем по приглашению Александра I поступил на дипломатическую службу в России. Участвовал в Венском конгрессе в 1815 г., в 1816 г. стал помощником министра иностранных дел К. В. Нессельроде. После отставки в 1827 г. уехал в Грецию, где был избран президентом страны; был убит в результате заговора 9 октября 1831 г. В 1868 г. был опубликован русский перевод адресованной им в 1826 г. Николаю I «Записка графа Иоанна Каподистриа о его служебной деятельности» ${ }^{20}$. Возможно, Достоевский читал письма графа Каподистрия, опубликованные в 1839 г. ${ }^{21}$ У Иоанна Каподистрия было два брата, также занимавшихся политической деятельностью, Августин (1778-1857) и Виаро Каподистрия (1770-1842). 


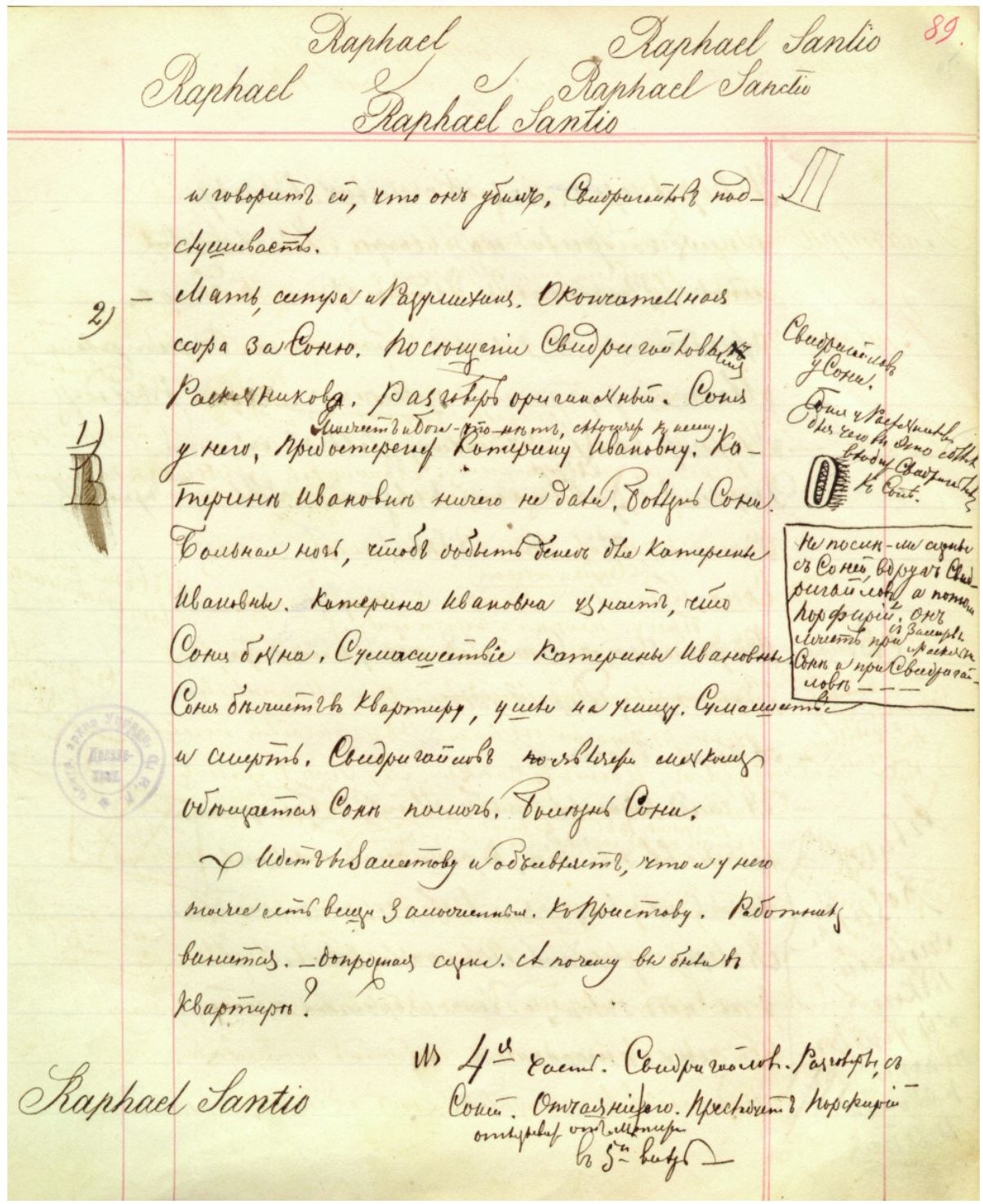

Илл. 17. РГАЛИ. Ф. 212.1.5. С. 89

«Raphael Sanctio <d'Urbino>» - картина Рафаэля «Сикстинская Мадонна» (1512-1513) была для Достоевского одним из высших достижений человеческой культуры за все время ее существования, наравне с «Дон Кихотом» М. де Сервантеса. Во время посещения Дрезденской галереи, как вспоминает его жена Анна Григорьевна, он восхищался картиной и стоял перед ней в молитвенном размышлении [Достоевская: 10, 12, 15, 24, 35]. 


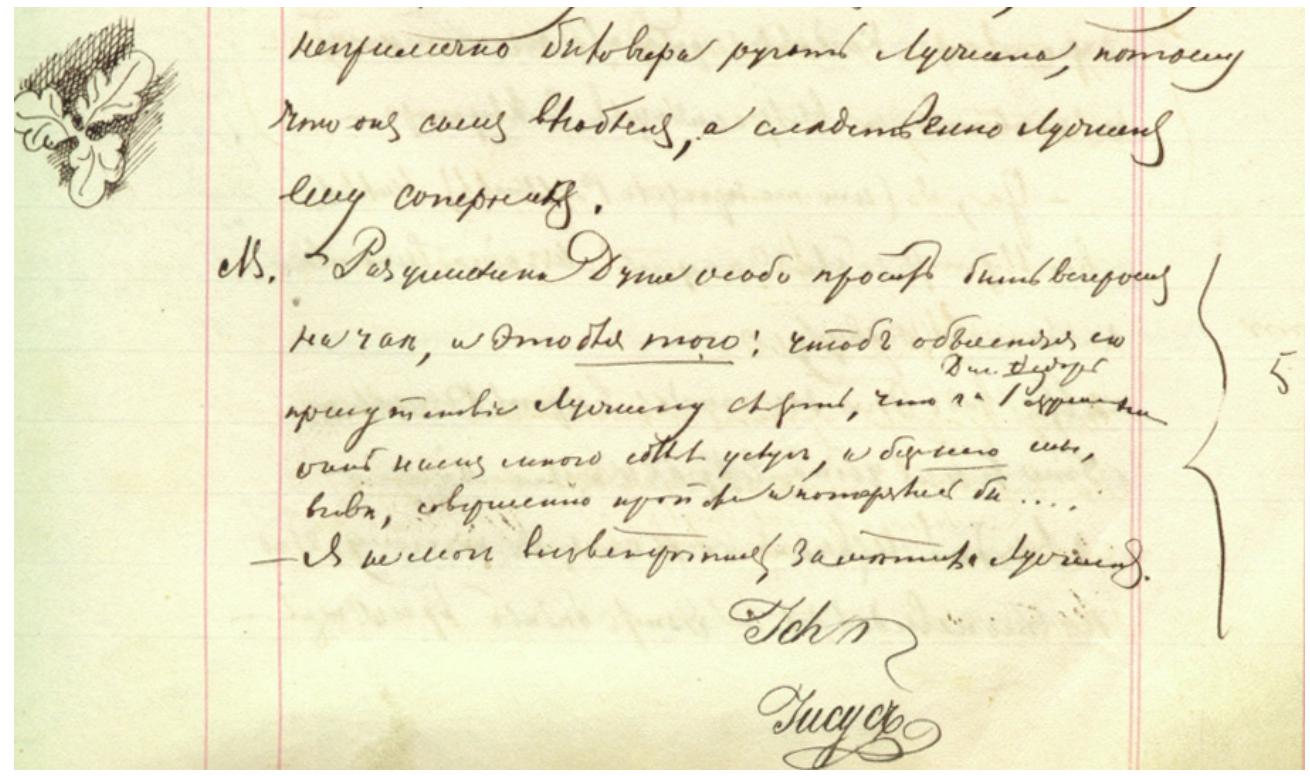

Илл. 18. РГАЛИ. Ф. 212.1.5. С. 99

Росчерки «Ich», «Иисус» сделаны в процессе разработки сцены чтения Евангелия Раскольниковым и Соней. В этом эпизоде воспроизведена цитата из Евангелия от Иоанна: “Иисус сказал ей: Я есмь воскресение и жизнь; верующий в Меня, если и умрет, оживет. И всякий живущий и верующий в Меня не умрет вовек. Веришь ли сему?" <...> Так, Господи! Я верую, что ты Христос, сын Божий, грядущий в мир» $(6 ; 250)$. Заметим, что слова: «Я есмь воскресение и жизнь» (Ин. 11:25) были подчеркнуты Достоевским в его экземпляре Евангелия [Евангелие Достоевского: 269]. Немецкий язык в написании личного местоимения, вероятно, связан с мыслью о книге немецкого философа Давида Фридриха Штрауса (нем. David Friedrich Strauß; 1808-1874) «Жизнь Иисуса»22. Достоевский брал эту книгу в 1847 г. в библиотеке Петрашевского 23 . В 1864 г. вышла новая версия этого труда под названием «Das Leben Jesu für das deutsche Volk bearbeitet» (Leipzig, 1864), в которой Штраус учел вышедшую годом ранее монографию Эрнеста Ренана «Vie de Jesus» (Paris, 1863). После издания дополненной версии «Жизни Иисуса» Штраус выпустил также философский труд «Der Christus des Glaubens und der Jesus der Geschichte, eine Kritik der Schleiermacher'schen Lebens Jesu» (Berlin, 1865). 


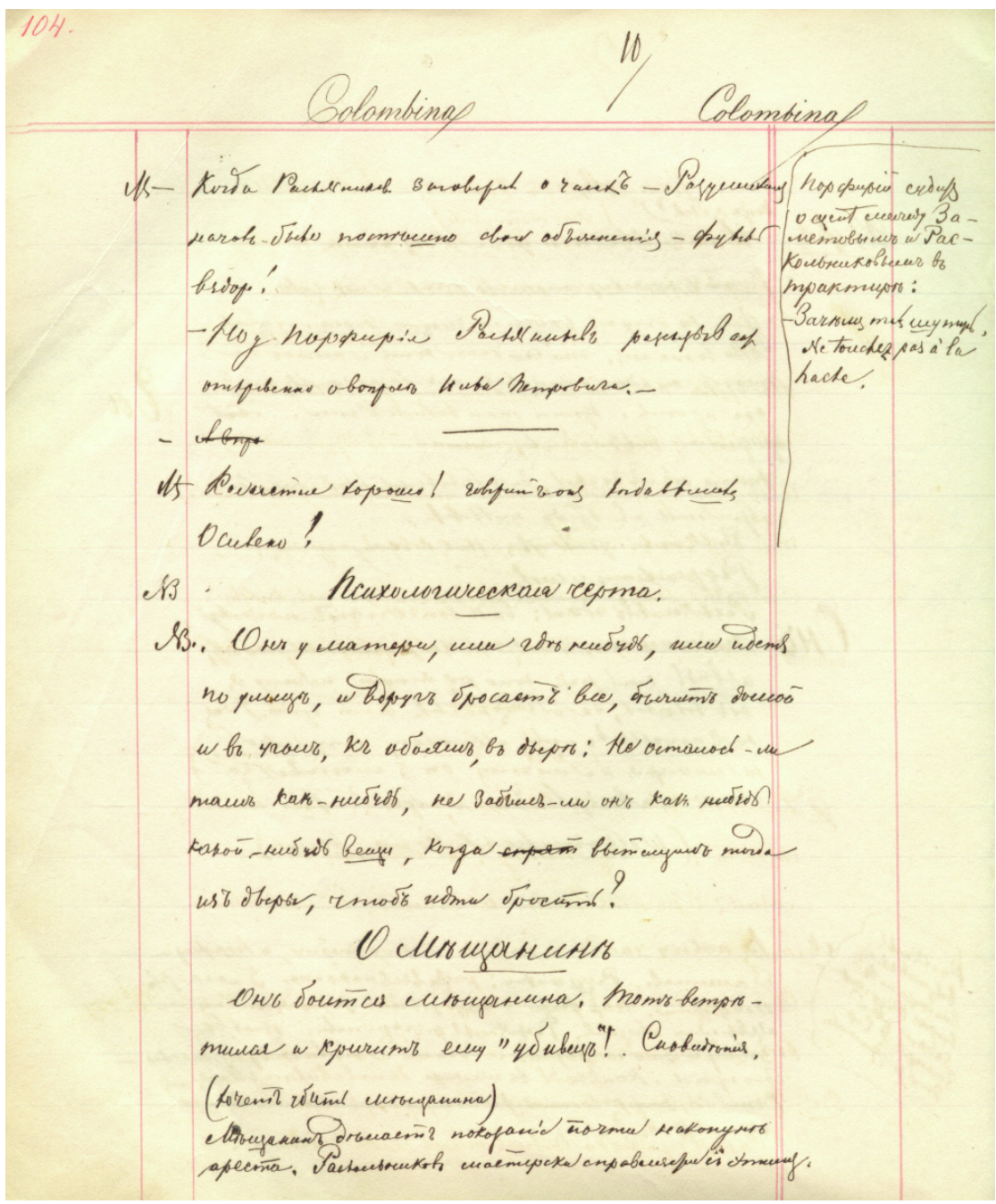

Илл. 19. РГАЛИ. Ф. 212.1.5. С. 104

«Colombina» - персонаж итальянской и французской комедии масок, пронырливая особа, как правило, находящаяся в центре сюжетной интриги и скрепляющая собой классический любовный треугольник: Арлекин, Коломбина, Пьеро. Пропись, вероятно, связана с разработкой писателем отношений соперничества между Разумихиным и Лужиным в их борьбе за Дуню Раскольникову: «Разумихин <...> понял, что ему неприлично было вчера ругать Лужина, потому что он сам влюблен, а следственно, Лужин ему соперник» $(7 ; 174)$. 


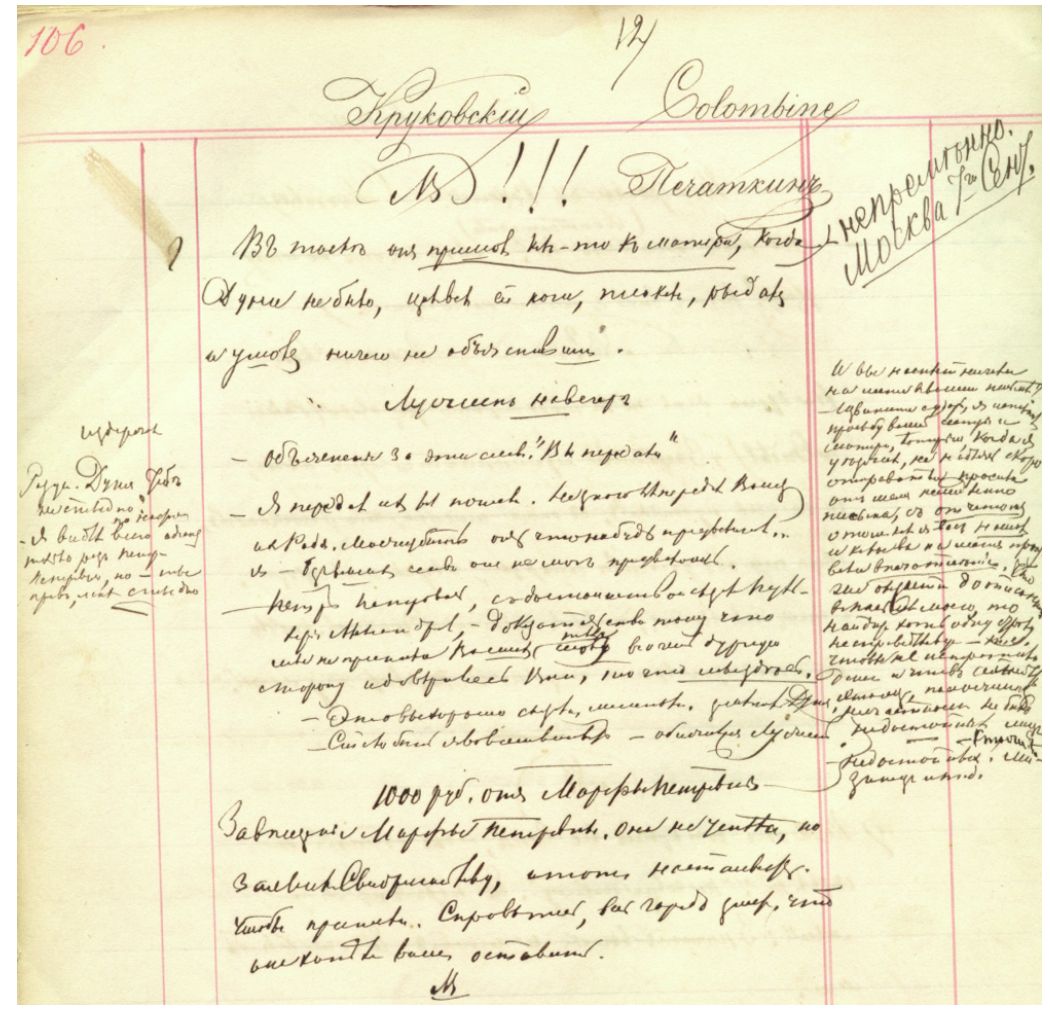

Илл. 20. РГАЛИ. Ф. 212.1.5. С. 106

«Круковский» - Василий Васильевич Корвин-Круковский (1803-1875), генерал-лейтенант; его дочь Анна Васильевна Корвин-Круковская (1843-1887) вопреки воле отца стала писательницей, сотрудничала с журналом братьев Достоевских «Эпоха», разместив там свою повесть «Сон» ${ }^{4}$. Достоевский вступил в переписку с молодой писательницей, одно из этих писем попалось на глаза ее отцу и после прочтения вызвало в нем недовольство. В феврале 1865 г. Достоевский и Корвин-Круковская встретились в Петербурге, он сделал ей предложение стать его женой, но получил отказ. Впоследствии А. В. Корвин-Круковская вышла замуж за французского революционера Ш.-В. Жаклара (1840-1903), участвовала в Парижской коммуне, стала членом Интернационала ${ }^{25}$.

«Печаткин» - один из трех братьев Печаткиных, издателей, владельцев Красносельской бумажной фабрики и книгопродавцев: Вячеслав Петрович (1819-1898), Константин Петрович (1818-1895), Евгений Петрович (1838-1918). Последний был членом подпольной революционной организации, неоднократно задерживался полицией за свою деятельность, в частности, распространение революционных прокламаций. 


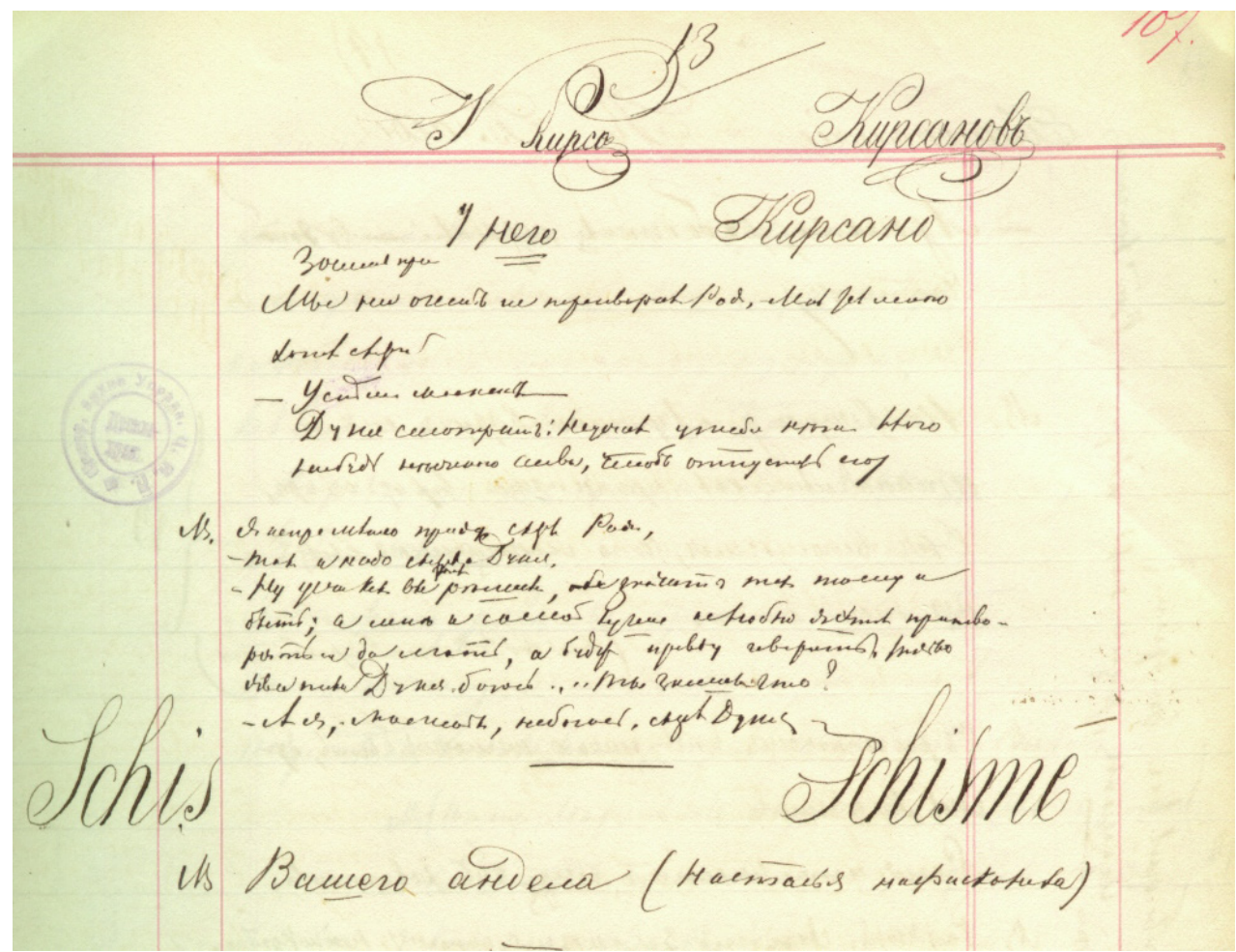

Илл. 21. РГАЛИ. Ф. 212.1.5. С. 107

«Кирса», «Кирсано», «Кирсанов» - вероятно, Павел Петрович Кирсанов, персонаж романа И. С. Тургенева «Отцы и дети», противник Базарова в их идейном противостоянии.

«Schis», «Schismé» - схизма, раскол, ересь, отступничество от веры, отпадение от Церкви. Пропись, вероятно, имеет отношение к семантике имени главного героя, а также к сюжету романа, завершающегося в эпилоге нравственным возрождением Раскольникова и его согласием преодолеть раскол с мирозданием, принять его в том виде, какой ранее был для него категорически неприемлем. Достоевского в 1860-е гг. живо интересовала история раскола в русской Церкви: он издавал на страницах своих журналов книги о старообрядчестве, многократно обращался к этой теме в своих произведениях. В основе трагедии русской истории, по Достоевскому, лежат два раскола: раскол между интеллигенцией и народом в результате реформ Петра I и, полувеком ранее, церковный раскол 1650-1660 гг., связанный с богослужебно-обрядовыми нововведениями патриарха Никона. 


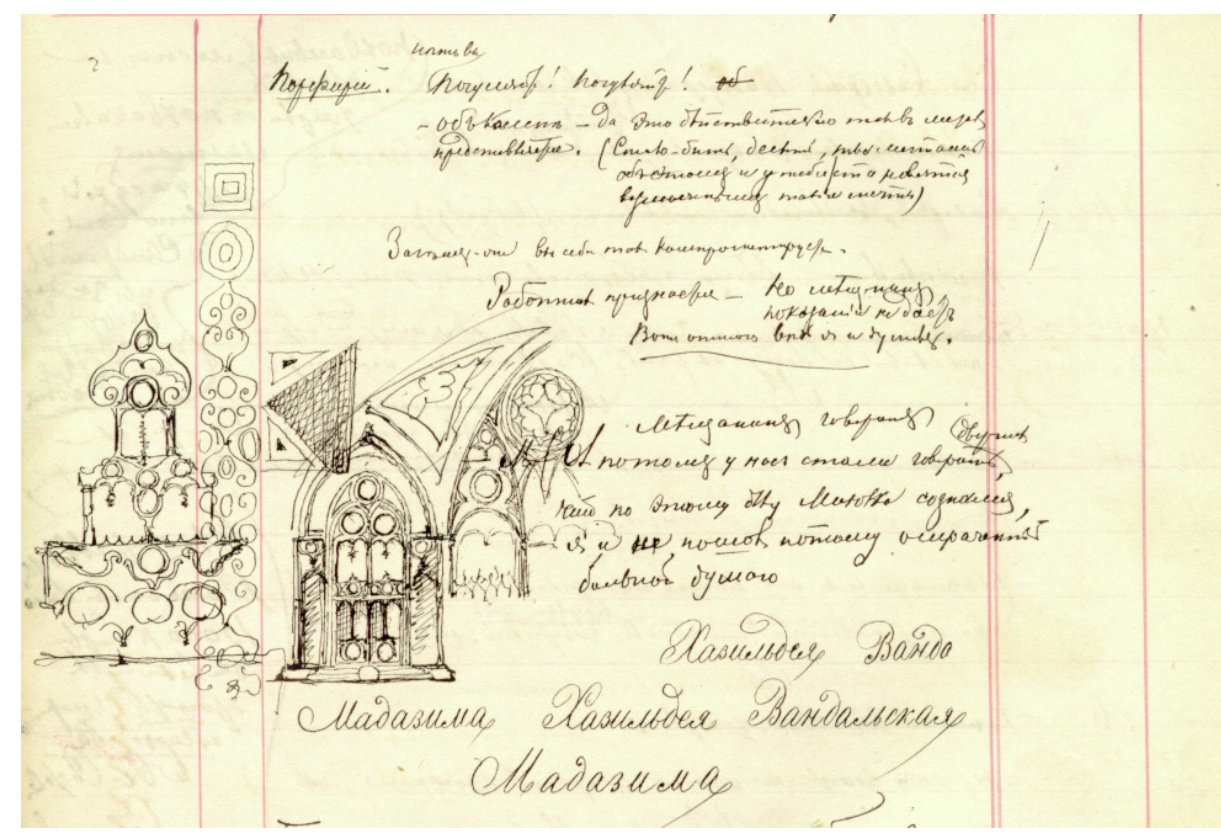

Илл. 22. РГАЛИ. Ф. 212.1.5. С. 130

«Хазильдея Вандальская» (2 р.), «Мадазима» (2 р.) - персонажи романа М. де Сервантеса «Дон Кихот», любимейшего произведения мировой литературы для Достоевского. Записи на странице показывают, что Достоевский был близок к решению наделить Раскольникова, действующего с оттенком безумия, донкихотским стилем поведения: «Порфирий мещанину в конце романа: - 3ачем же ты не являлся? Ведь это улика, я бы его тогда посадил, но вот что я тебе скажу. Теперь нельзя посадить. Я изучил: болезненное состояние (было тогда), странность поведения, почти сумасшествие и после того все приемы, все поступки не то что не оправдывают, но даже противоречат» (7; 193-194). Записи связаны с характеристикой действий Раскольникова, сражающегося со злом и безуспешно пытающегося спасти от бедности и позора своих мать и сестру, Соню Мармеладову и весь мир в целом. Основной темой этих размышлений было поражение добра при столкновении со злом; размышляя о безуспешной попытке Раскольникова спасти сестру Авдотью Романовну от позорного, на его взгляд, брака с Лужиным, Достоевский вспоминал о тяжком поражении Дон Кихота в борьбе за честь королевы Мадасимы, описанном в 24-й главе первой части романа Сервантеса, а также имя другой красавицы, Касильдеи Вандальской, выше которой, по мнению Дон Кихота, только Дульсинея. Позже в «Дневнике Писателя» Достоевский рассказал о горьком чувстве, которое испытал Г. Гейне, читая о том, как Дон Кихота побеждает «презренный и здравомыслящий цирюльник Самсон Караско» и затем помещает его, связанного, в клетку $(22 ; 92)$. 


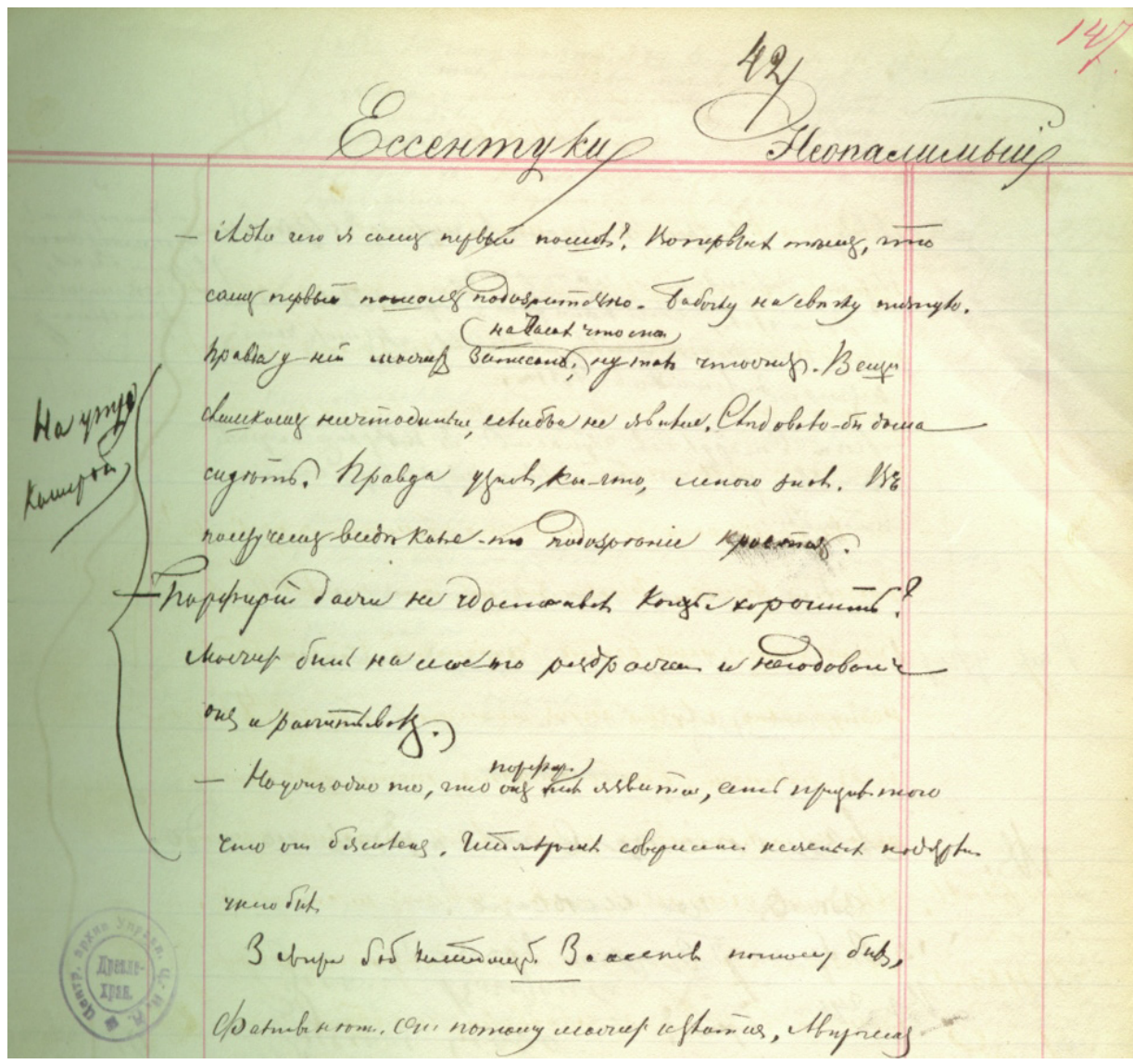

Илл. 23. РГАЛИ. Ф. 212.1.5. С. 14

«Ессентуки» - этот город, наряду с Баден-Баденом, Эмсом и Старой Руссой, рассматривался Достоевским в качестве возможного места для лечения минеральными водами.

«Неопалимыци» - неопалимая купина, горящий и несгорающий терновый куст, в виде которого, согласно Библии, Моисею явился ангел Господень (Исх. 3:2). 


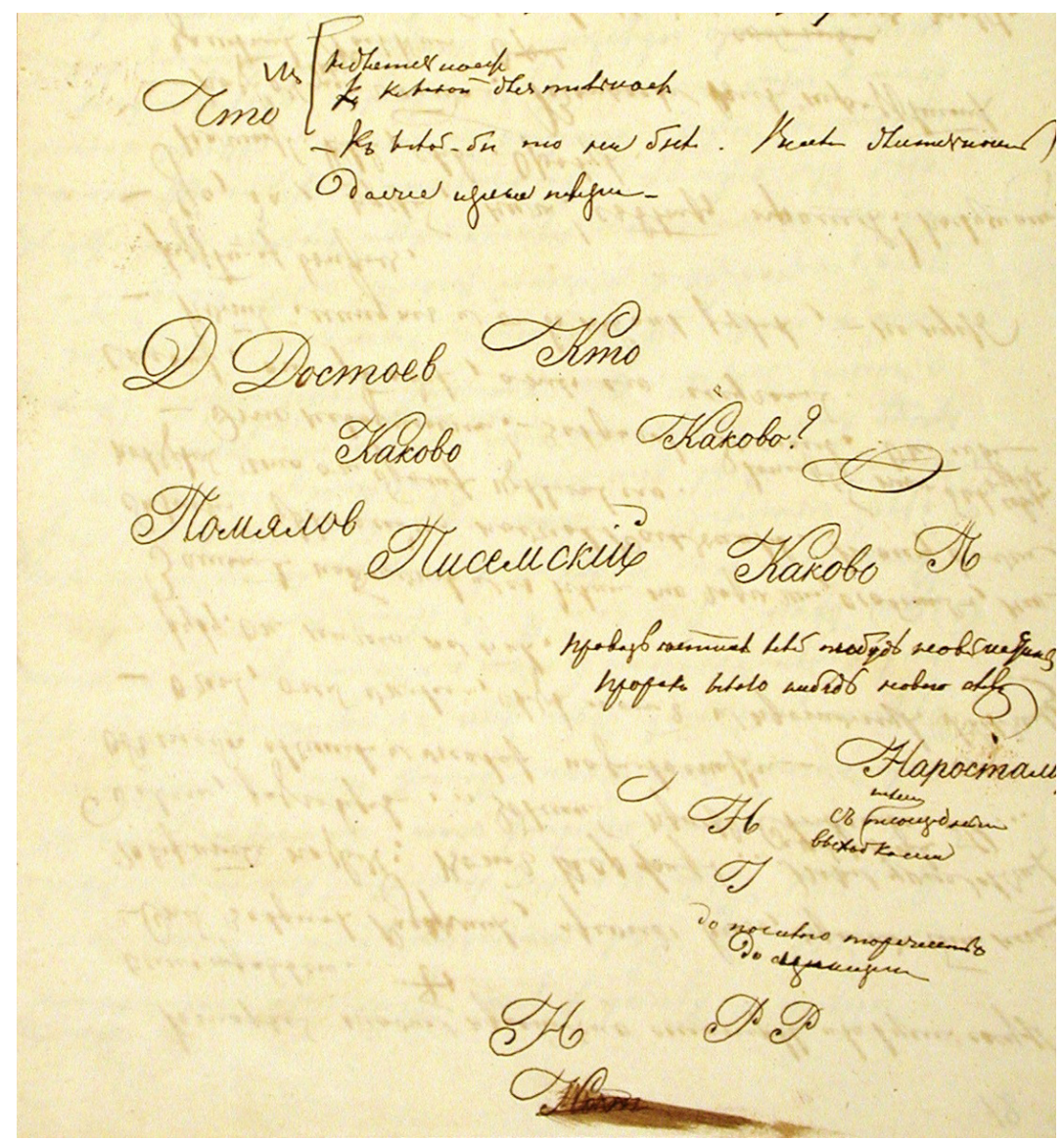

Илл. 24. НИОР РГБ. Ф. 93.I.1.2/5. Л. 2 об.

"Что», «Кто»" «Каково» (3 р., из них - 1 р. со знаком вопроса), «Помялов<ский>», «Писемский», «Достоев<ский>»: в центре размышлений Достоевского о современной русской литературе, запечатленных в этих прописях, были Н. Г. Чернышевский (1828-1889), автор романа «Что делать?» (1862), А. И. Герцен (1812-1870), публицист, писатель и издатель, автор одного из самых крупных литературных явлений 1840-х гг., повести «Кто виноват?» (1846), прозаик-бытописатель А. Ф. Писемский (1821-1881), автор антинигилистического романа «Взбаламученное море» (1863), также поднимавший тему протестных настроений среди «новых людей» в русском обществе и Н. Г. Помяловский (1835-1863), самыми известными произведениями которого стали «Мещанское счастье» и «Молотов» (1861). 


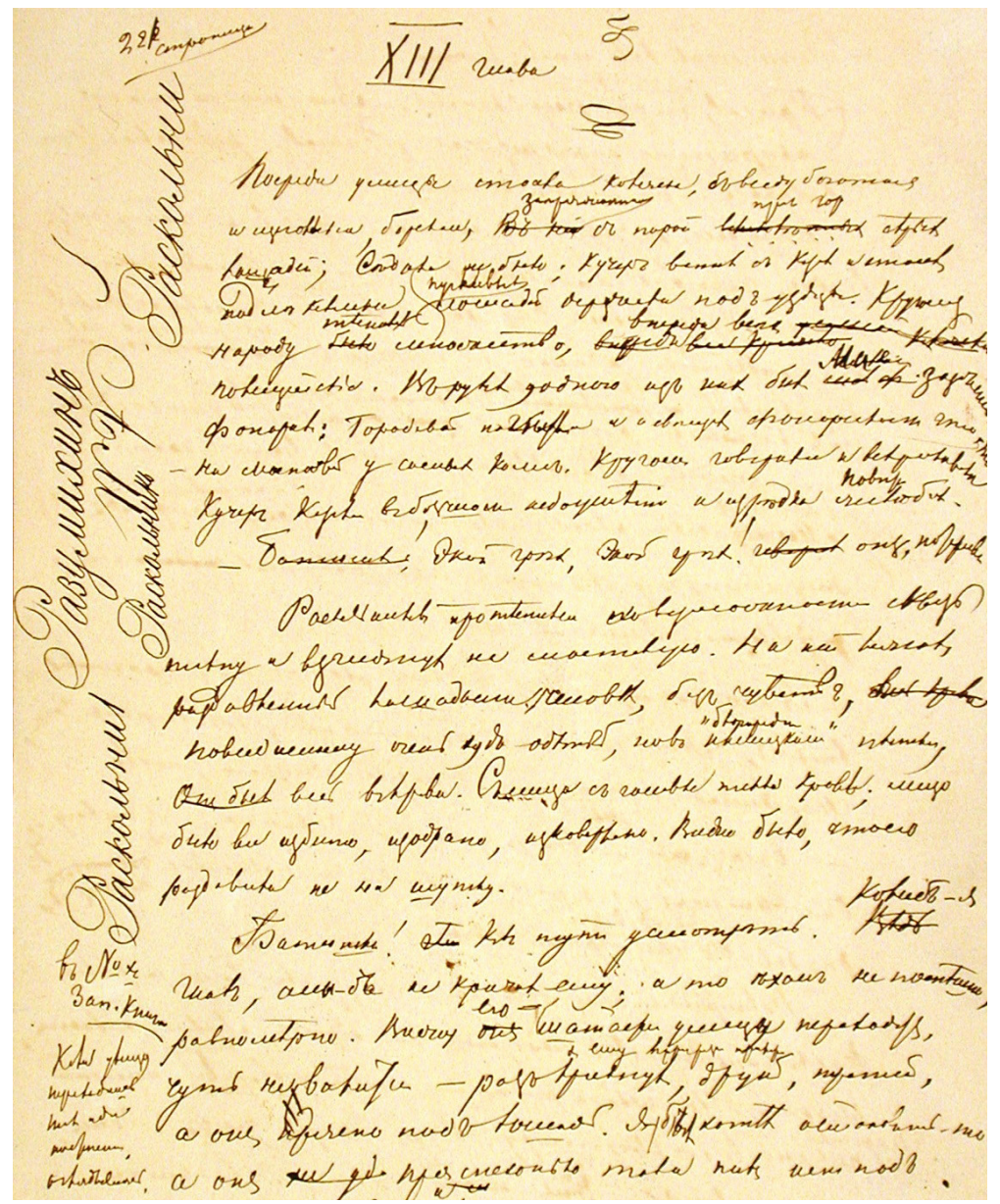

Илл. 25. НИОР РГБ. Ф. 93.I.1.2/4. Л. 1

«Раскольни<ков>», «Разумихин» - Родион Романович Раскольников, Дмитрий Прокофьевич Разумихин - действующие лица «Преступления и Наказания».

«A $\boldsymbol{M}$ » - вероятно, обозначает инициалы еще одного персонажа романа «Преступление и Наказание», Мармеладова. Страница, на которой находится запись, посвящена разработке сцены гибели Мармеладова под колесами конной коляски («с виду богатой и щегольской, барской» - 7; 320). На этом этапе разработки эпизода Мармеладов именовался Аркадием Семенычем или Аркадием Степанычем и лишь затем, в окончательной версии романа, получил имя Семена Захарыча. Страница помечена как «XIII глава» - по нумерации версии, опубликованной в «Русском Вестнике» ${ }^{26}$, в окончательной редакции романа это 7-я глава второй части «Преступления и Наказания» (6; 136-151). 


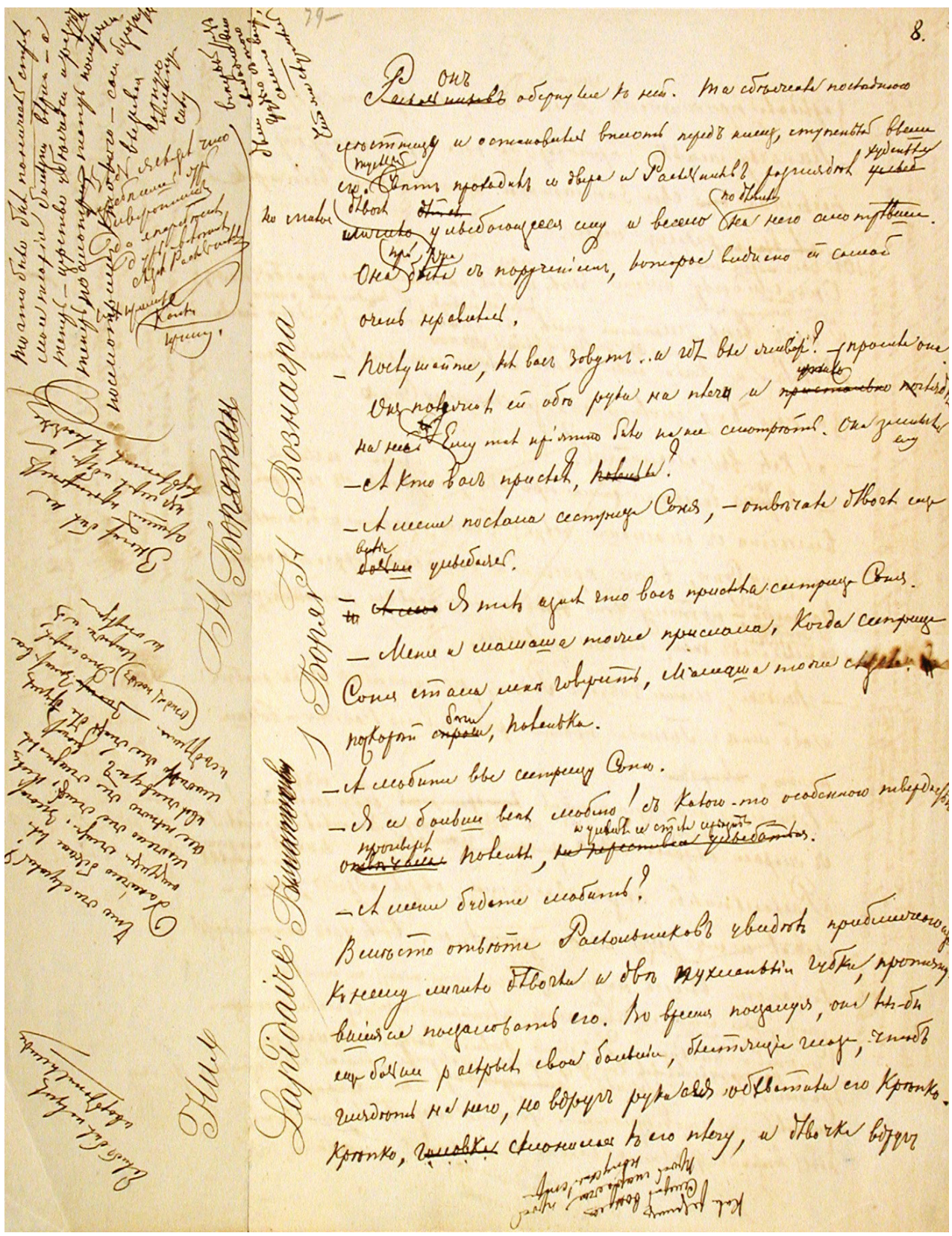

Илл. 26. НИОР РГБ. Ф. 93.I.1.2/4. Л. 8

«Lapidaire» (фр. краткий) - здесь: сжатый, ясно выраженный стиль изложения. На всем протяжении работы своей над произведением Достоевский 
постоянно призывал себя излагать события «как можно короче», «оригинальнее и короче» $(7 ; 35,82,84)$.

«Боря<тинский>» - согласно мнению Р. Г. Назирова, Достоевский в процессе разработки образа «Князя» в романе «Бесы» (будущего Ставрогина) ориентировался на характер генерал-фельдмаршала, князя А. И. Барятинского (1815-1879), русского государственного и военного деятеля, главнокомандующего русскими войсками на Кавказе и, далее, наместника императора [Назиров]. Известный как «покоритель Кавказа», Барятинский имел также репутацию человека с низким уровнем социальной ответственности, блистательного аристократа с консервативными убеждениями, скучающего и ищущего развлечений денди.

«Вознагра<ждать>» - вероятно, относится к формированию диалога между Катериной Ивановной и Раскольниковым у смертного одра Мармеладова: «Быть может, те, которые были невольною причиной, согласятся вознаградить вас, хоть бы в потере доходов... - Не понимаете вы меня! раздражительно крикнула Катерина Ивановна, махнув рукой. - Да и за что вознаграждать-то? Ведь он сам, пьяный, под лошадей полез! Каких доходов? От него не доходы, а только мука была» (6; 144). 


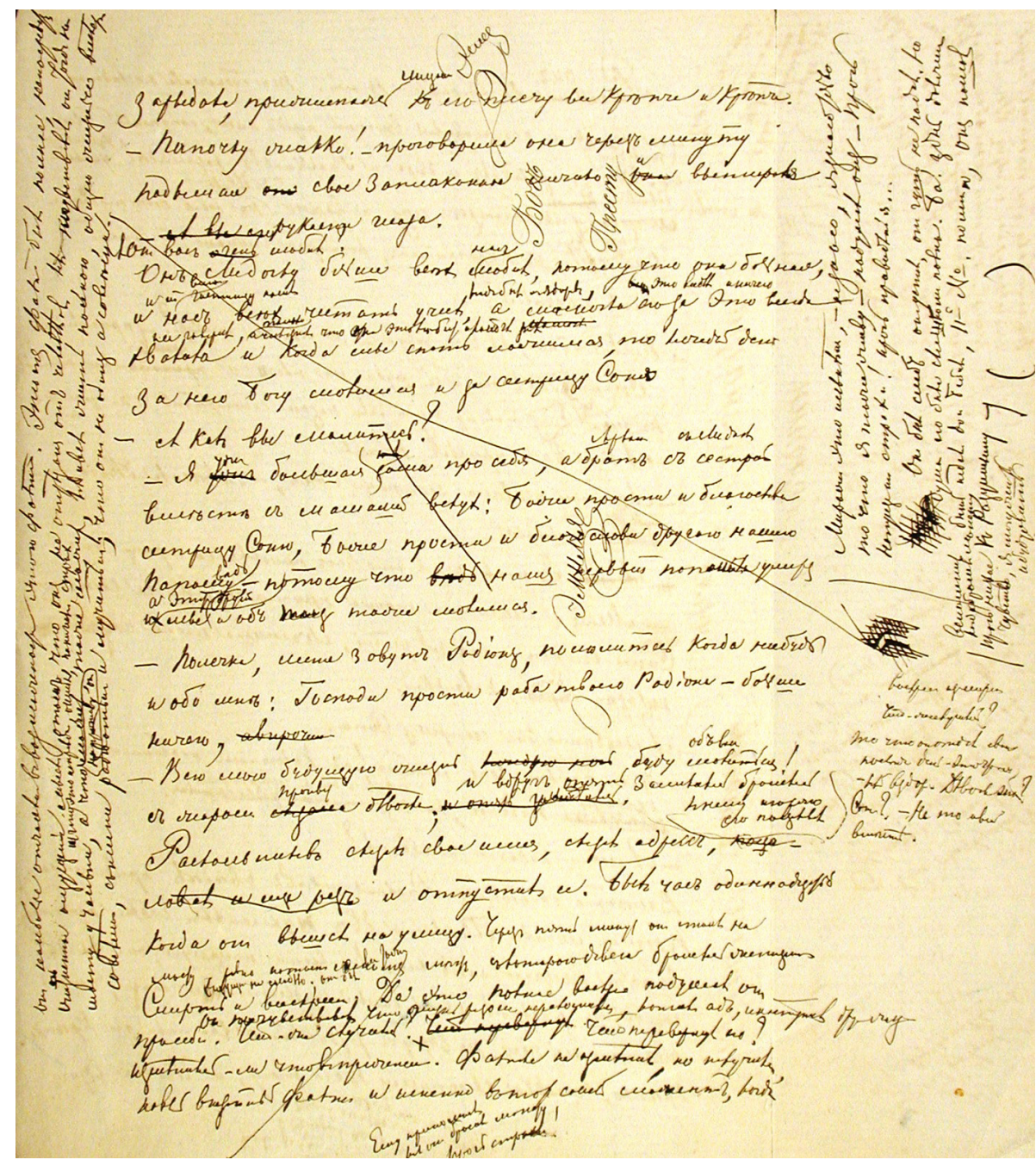

Илл. 27. НИОР РГБ. Ф. 93.І.1.2/4. Л. 8 об.

Каллиграфические записи: «Престу<пление >», «Бог» - центральные пункты идеологии романа «Преступление и Наказание». Нравственное состояние человека зависит от его религиозных взглядов, считал Достоевский, в то время как отпадение от Бога чревато принятием принципа «все позволено» и ведет к его практической реализации: насилию над ближним или убийству.

Запись «Эмилия», вероятно, относится к Эмилии Федоровне Достоевской (Дитмар) (1821-1879), жене старшего брата писателя М. М. Достоевского (с 1842 г.). 


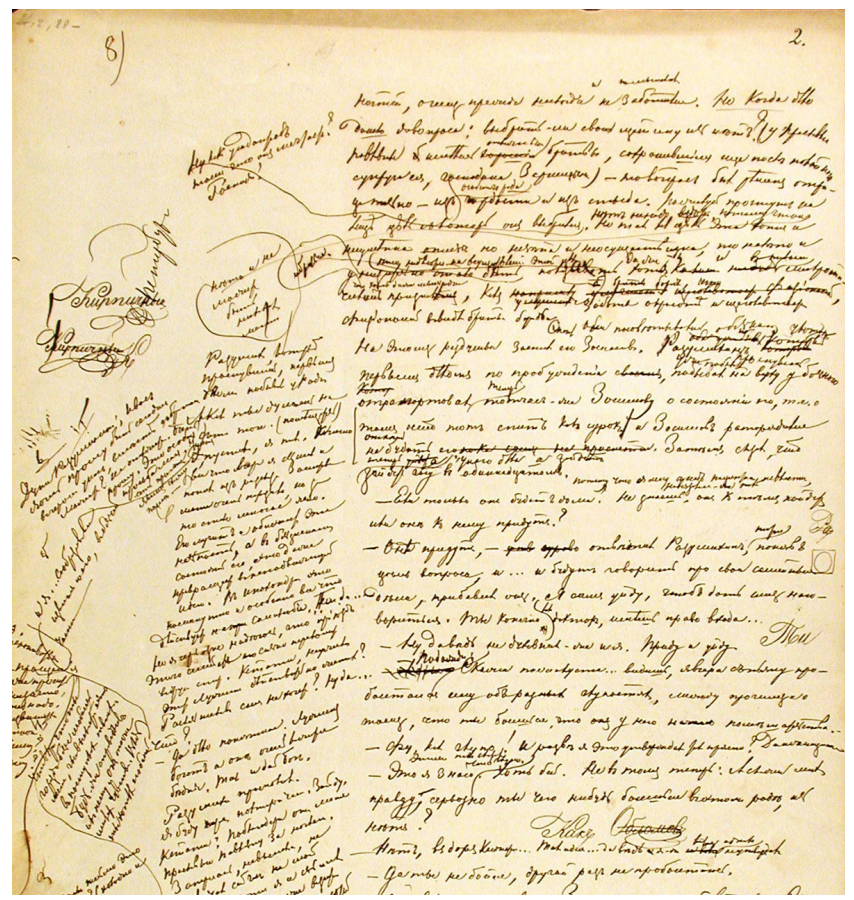

Илл. 28. НИОР РГБ. Ф. 93.І.1.2/9. Л. 2

«Кирпичный» - вероятно, имеется в виду Кирпичный переулок. Достоевскому было хорошо знакомо это место. В рукописи «Двойника»есть текст: «Справляется о Гарибальди в разных министерствах. Секрет-с. За гривенник достает адресс: статский советник в отставке, в Кирпичном переулке, № 31-й. Идет в Кирпичный переулок, ждет. Лакей выпроваживает. (Я у Гайбурского)» $(1 ; 436)$. Согласно данным Н. П. Анциферова, писатель снимал «квартиру в Кирпичном переулке (дом не установлен)» [Анциферов: 27], эти данные подтверждают редакторы Полного собрания сочинений Ф. М. Достоевского $(1 ; 499)$ и С. В. Белов [Белов: 357]; именно здесь состоялось его знакомство с М. В. Петрашевским. Согласно мнению Б. Н. Тихомирова, это ошибка, тиражированная многими исследователями из-за неправильной датировки доктором Яновским своего знакомства с Достоевским (не 1846, a 1847 г.) - с конца весны 1846 г. некоторое время писатель жил в Троицком переулке (см.: [Тихомиров, 2016: 38-40]). В этот период у Достоевского, как и у Раскольникова, были тяжелые материальные обстоятельства, в мае 1846 г. брату Михаилу Михайловичу он сообщает: «Денег у меня нет ни копейки, да и не знаю еще, откуда я их получу»; «У меня в последнее время были все разные квартиры, и вообще преобладал около меня беспорядок» $(28 ; 123,124)$. 


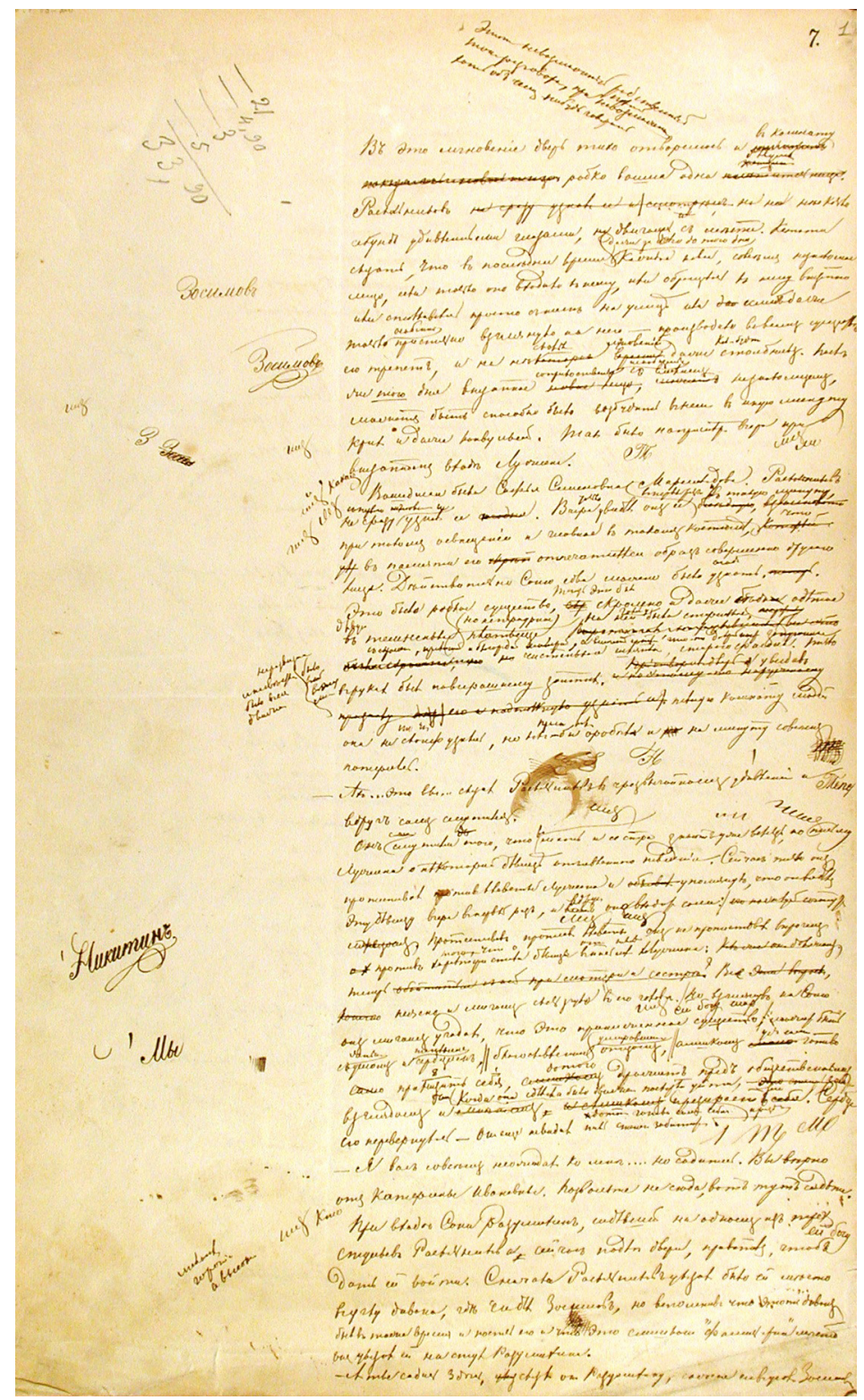

Илл. 29. НИОР РГБ. Ф. 93.I.1.2/13. Л. 1

«Зосимов» - персонаж романа «Преступление и Наказание», доктор, приглашенный Разумихиным к Раскольникову во время его болезни.

«Никитин» - вероятно, Иван Саввич Никитин (1824-1861), русский поэт, последователь Н. А. Некрасова, автор произведений, описывающих быт 
простого народа и тяжелую участь неимущих слоев общества; его произведения не были приняты современной ему критикой. Достоевский защищал Никитина от жестких обвинений Н. А. Добролюбова в своей статье «Г-н -бов и вопрос об искусстве», считая, что тот обошелся с Никитиным «деспотически» (18; 102-103). В 1863 г. Достоевский печатался вместе с Никитиным в сборнике, изданном землевольцем А. Д. Путятой ${ }^{27}$, куда вошли глава «Акулькин муж» из его «Записок из Мертвого дома» и известное стихотворение И. С. Никитина «Бурлак».

«Mb», «Tenep<b>»- следы творческого размышления Достоевского, в процессе которого ему было необходимо закреплять на бумаге в виде каллиграфической прописи опорные пункты задуманных сюжетных линий.

Изучение каллиграфических прописей Достоевского расширяет словарь языка писателя, вводя в научный оборот новые имена, понятия и события. Зафиксированный в них процесс перевода художественного образа-впечатления в дискретный условный знак раскрывает новые черты в творческой работе Достоевского-философа. Идеографическая запись предоставляла особые условия для реализации свидетельствования о другом и формирования автономной, внешней по отношению к автору точки зрения на мир. Работая с большими пластами смыслов, обозначенными символическим письмом, каллиграфической прописью, Достоевский связывал хронотоп своего произведения с сюжетом Мировой Истории. Каллиграфические записи показывают, как формировался нарратив писателя на самом раннем этапе осуществления художественного замысла.

\section{ПРИМЕЧАНИЯ}

1 Эта мысль прозвучала в комментариях к первым публикациям записных тетрадей в начале 1920-х гг. См., напр.: [Из архива Ф. М. Достоевского: «Преступление и наказание»...: 6], [Из архива Ф. М. Достоевского: «Идиот»...: 4-6].

2 См. также: [Баршт, 1996: 6-14].

3 См. работы автора статьи: [Баршт, 1996, 2005, 2016].

4 См.: Записная книжка (1-ая) Ф. М. Достоевского: дипломатическая транскрипция [Электронный ресурс]. URL: http://lib2.pushkinskijdom.ru/записная-тетрадь-o-1дипломатическая-транскрипция.

5 «Между первоначальным сообщением и вторичным кодом возникает напряжение, под влиянием которого появляется тенденция истолковывать семантические элементы текста как включенные в дополнительную синтагматическую конструкцию и получающие от взаимной соотнесенности новые - реляционные - значения». См.: [Лотман: 171].

6 Достоевский Ф. М. Полн. собр. соч. и писем: в 35 т. 2-е изд., испр. и доп. СПб., 2016. Т. 5. С. 358.

7 Достоевский Ф. М. Полн. собр. соч.: в 30 т. Л.: Наука, 1972. Т. 3. С. 105. Далее ссылки на это издание приводятся в тексте статьи с указанием тома, книги (нижний индекс), страницы в круглых скобках.

8 См.: Положение о порядке производства в чины по гражданской службе (от 25 июня 1834 г.) // Полное собрание законов Российской империи. Собр. 2-е. СПб., 1935. Т. 9. Отд. 1. С. 659. 
9 См. об этом, напр.: [Фаликова].

10 Дефо Д. Жизнь и приключения Робинсона Крузо, описанные им самим / соч. Д. Дефо; новый пер. с англ. П. А. Корсакова. Издание украшено 200 рис. Гранвиля. СПб., 1842-1843. Ч. $1-2$.

11 См. об этом: [Баршт, 2015: 94-105].

12 Достоевский, по-видимому, имел лишь начальные сведения о древнегреческом языке. На это указывает то, что он пишет слово неправильно: вторая буква в его написании более напоминает латинскую букву «V», чем греческую «৩», четвертая буква должна быть

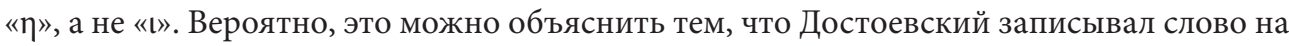
слух с рейхлинова произношения, используемого, в частности, в церковном греческом языке, где буква «эта» произносится как «и». Влиянием латинского языка можно объяснить и точку над «і» (комментарий составлен с помощью доцента кафедры классической филологии, русской литературы и журналистики Петрозаводского университета А. А. Скоропадской и профессора Веронского университета Ст. Алоэ).

13 Следует отметить, что в словаре языка Ф. М. Достоевского слово «проститутка» не обнаружено. Писатель временами позволял себе употребление более жесткого синонима этого понятия, однако здесь следует учесть, что вряд ли предпринял бы попытку введения этого термина в беловую версию произведения: этого не позволили бы ни редакторы «Русского Вестника», ни цензура.

14 Байрон Дж. Г. Манфред, драматическая поэма в трех действиях. Сочинение лорда Байрона / пер. с англ. М. В. СПб., 1828; Байрон Дж. Г. Манфред. Драматическая поэма в трех действиях. Соч. лорда Байрона / пер. с англ. А. Бородина // Пантеон русского и всех европейских театров. 1841. Ч. 1. Кн. 2. С. 1-24.

15 Oeuvres complètes de Voltaire. Nouvelle édition. Paris, 1817. Vol. 7. P. 618.

16 Полн. собр. соч. Козьмы Пруткова. 4-е изд. СПб., 1894. С. 100.

17 РО ИРЛИ. Ф. 407 (архив А. И. Порецкого), № 1. Л. 1.

18 См.: Санкт-Петербургские Ведомости. 1847. № 8. 11 января; № 24. 30 января.

19 Лекции из средней истории Т. Н. Грановского. І. Введение в историю Средних веков. II. Юлий Цезарь. III. Римская империя при первых императорах // Время. 1862. № 4. Апрель. С. 5-40; Лекции из средней истории Т. Н. Грановского. Глава IV. Август. Тиверий. Калигула. Клавдий. Нерон // Время. 1862. № 6. Июнь. С. 75-98.

20 «Записка графа Иоанна Каподистриа о его служебной деятельности». Перевод и примеч. К. К. Злобина // Сборник Императорского Русского исторического общества. СПб., 1868. T. 3. C. $163-296$.

21 «Correspondance du comte J. Capodistrias, président de la Grèce, comprenant sles lettres diplomatiques, administratives et particulières». Genève; Paris, 1839.

22 Das Leben Jesu, kritisch bearbeitet von David Friedrich Strauß. Bd. 1-2. Tübingen, 1835-36 (4-е изд.: Tubingen, 1840).

23 См.: Кийко Е. И. Комментарий // Достоевский Ф. М. Собр. соч. в 15 т. Т. 12. Дневник писателя. 1873. СПб., 1994. С. 297.

24 О-в Ю. [Корвин-Круковская А. В.] Сон // Эпоха. 1864. № 8. С. 1-24; 6-я пагинация.

25 См.: [Книжник-Ветров].

26 Достоевский Ф. М. Преступление и Наказание // «Русский Вестник». 1866. № 2. С. 556-574.

27 Сборник рассказов. В прозе и стихах. СПб., 1863. 


\section{СПИСОК ЛИТЕРАТУРЫ}

1. Анциферов Н. П. Петербург Достоевского. - П.: Изд-во Брокгауз-Ефрон 1923. Репринтное воспроизведение. - М.: Книга, 1991. - 106 с.

2. Баршт К. А., Тороп П. Х. Рукописи Ф. М. Достоевского: Рисунок и каллиграфия // Текст и культура. Семиотика. Труды по знаковым системам, XVI. - Тарту, 1983. C. $135-152$.

3. Баршт К. А. Рисунки в рукописях Ф. М. Достоевского. - СПб.: Формика, 1996. - 319 с.

4. Баршт К. А. Рисунки в рукописях Ф. М. Достоевского; Портретные рисунки Ф. М. Достоевского к роману «Преступление и наказание». CD-ROM, мультимедийный альбом. СПб., 1999.

5. Баршт К. А. Языки творческой рукописи Ф. М. Достоевского // Языки рукописей: сб. ст. - СПб., 2000. - С. 122-147.

6. Баршт К. А. Рисунки Ф. М. Достоевского: Каталог // Достоевский Ф. М. Полн. собр. соч.: в 18 т. - М.: «Воскресенье», 2005. - Т. 17. - С. 6-676.

7. Баршт К. А. Имя и философия Николая Мальбранша в черновых записях и произведениях Достоевского // Вопросы философии. - 2015. - № 2. - С. 94-105.

8. Баршт К. А. Рисунки и каллиграфия Ф. М. Достоевского. От изображения к слову. Бергамо: Lemma-Press, 2016. - 456 c.

9. Белинский В. Г. Полн. собр. соч.: в 13 т. - М.: Изд-во АН СССР, 1955. - Т. 6: Статьи и рецензии. 1842-1843. - 799 с.

10. Белов С. В. Петербург Достоевского. - СПб.: Алетейя, 2002. - 372 с.

11. Бочаров С. Г. Французский эпиграф к «Евгению Онегину» (Онегин и Ставрогин) // Московский пушкинист: ежегод. сб. - М.: Наследие, 1995. - Вып. І. - С. 212-250.

12. Выготский Л. С. Мышление и речь. - М.; Л.: ОГИЗ-СОЦЭКГИЗ, 1934. - 323 с.

13. Достоевская А. Г. Дневник 1867 года. - М.: Наука, 1993. - 456 с.

14. Евангелие Достоевского: в 2 т. / подгот. текста, коммент. В. Н. Захарова, В. Ф. Молчанова, Б. Н. Тихомирова. - М.: Русскій Міръ, 2010. - Т. 1: Личный экземпляр Нового Завета 1823 года издания, подаренный Ф. М. Достоевскому в Тобольске в январе 1850 года. - $656 \mathrm{c.}$

15. Из архива Ф. М. Достоевского: «Идиот»: Неизданные материалы. - М.; Л.: ГИХЛ, 1931. $-320 \mathrm{c}$.

16. Из архива Ф. М. Достоевского: «Преступление и наказание»: Неизданные материалы. М.; Л.: ГИХЛ, 1931. - 219 с.

17. Книжник-Ветров И. В. А. В. Корвин-Круковская (Жаклар): друг Ф. М. Достоевского, деятельница Парижской коммуны. - М.: Изд-во Всесоюз. общ-ва политкаторжан и ссыльно-переселенцев, 1931. - 116 с.

18. Лотман Ю. М. Внутри мыслящих миров // Лотман Ю. М. Семиосфера. - СПб.: Искусство-СПБ, 2000. - С. 150-390.

19. Назиров Р. Г. К вопросу о прототипе Ставрогина // Назиров Р. Г. О мифологии и литературе, или Преодоление смерти: Статьи и исследования разных лет. - Уфа, 2010. C. 297-308.

20. Тихомиров Б. Н. «А живу в доме Шиля...»: Адреса Ф. М. Достоевского в Петербурге, известные и неизвестные. 1837-1881. - СПб.: Серебряный век, 2016. - 151 с.

21. Тихомиров Б. Н. Был ли у Достоевского неосуществленный замысел под названием «Ростовщик»? // Неизвестный Достоевский. - 2017. — № 3. - С. 3-15 [Электронный pecypc]. — URL: http://unknown-dostoevsky.ru/files/redaktor_pdf/1508167445.pdf (15.05.2018). 
22. Фаликова Н. Э. Американские мотивы в поздних романах Ф. М. Достоевского // Новые аспекты в изучении Достоевского. - Петрозаводск, 1994. - С. 199-241.

23. Ф. М. Достоевский в воспоминаниях современников: в 2 т. - М.: Худож. лит., 1990. T. $1 .-622 \mathrm{c}$.

24.Эфрос А. М. Рисунки поэта. - М.: Academia, 1933. - 472 с.

Дата поступления в редакичю: 18.08.2018

Konstantin A. Barsht

Doctor of Philology, Professor, Leading Researcher of the Institute of Russian Literature (Pushkinskiy Dom),

Russian Academy of Sciences

(St. Petersburg, Russian Federation)

konstantin_barsht@pushdom.ru

\title{
The Calligraphy of Fedor Dostoevsky in His Manuscripts to the Novel "Crime and Punishment"
}

\begin{abstract}
The article analyzes the calligraphic records from the preparatory materials for the novel "Crime and Punishment" by Fedor Dostoevsky, contained in three notebooks (the Russian State Archive of Literature and Art. Fund 212.1.3-5). The author of the research paper puts forward the idea that all the languages in which the writer used to put down the information during his work, including the language of ideographic writing elaborated by Dostoevsky himself, require a new approach that would not distinguish the verbal and ideographic languages in the writer's manuscript. Calligraphic notes made by Dostoevsky during his work keep record of new names, concepts and events that are absent in the printed texts by Dostoevsky and up to now remain little-studied and unclaimed, in spite of being an important source of information about the history of his works. This article fills the gap formed due to the inattention of the publishers of Dostoevsky's texts paid to his ideographic notes made during the work on the novel "Crime and Punishment" and constituting a single information and semantic whole with all the other entries in his notebooks of 1864-1866.
\end{abstract}

Keywords: F. M. Dostoevsky, textual science, calligraphy, “Crime and Punishment”, creative process, nonverbal language

\section{REFERENCES}

1. Antsiferov N. P. Peterburg Dostoevskogo [Petersburg of Dostoevsky]. Petrograd, Brokgauz-Efron Publ., 1923. Reprint Reproduction. Moscow, Kniga Publ., 1991. 106 p. (In Russ.)

2. Barsht K. A., Torop P. X. Manuscripts of F. M. Dostoevsky: Illustration and Calligraphy. In: Tekst i kul'tura. Semiotika. Trudy po znakovym sistemam, XVI [Text and Culture. Semiotics. Sign Systems Studies, 16]. Tartu, 1983, pp. 135-152. (In Russ.)

3. Barsht K. A. Risunki v rukopisyakh F. M. Dostoevskogo [Illustrations in the Manuscripts of Dostoevsky]. St. Petersburg, Formika Publ., 1996. 319 p. (In Russ.)

4. Barsht K. A. Risunki v rukopisyakh F. M. Dostoevskogo; Portretnye risunki F. M. Dostoevskogo k romanu "Prestuplenie i nakazanie» [Illustrations in the Manuscripts of Dostoevsky; Portrait Drawings by F. M. Dostoevsky for the Novel "Crime and Punishment"]. St. Petersburg, 1999. CD-ROM, Multimedia Album (In Russ.) 
5. Barsht K. A. The Languages of the Original Manuscript of F. M. Dostoevsky. In: Yazyki rukopisey: Sbornik statey [Manuscript Languages: Digest of Articles]. St. Petersburg, 2000, pp. 122-147. (In Russ.)

6. Barsht K. A. Illustrations of F. M. Dostoevsky: Catalog. In: Dostoevskiy F. M. Polnoe sobranie sochineniy: $v 18$ tomakh [Dostoevsky F. M. The Complete Works: in 18 Vols]. Moscow, Voskresen'e Publ., 2005, vol. 17, pp. 6-676. (In Russ.)

7. Barsht K. A. The Name and Philosophy of Nicolas Malebranche in Drafts and Works of Dostoevsky. In: Voprosy filosofii, 2015, no. 2, pp. 94-105. (In Russ.)

8. Barsht K. A. Risunki i kalligrafiya F. M. Dostoevskogo. Ot izobrazheniya k slovu [Illustrations and Calligraphy of F. M. Dostoevsky. From Image to Word]. Bergamo, Lemma-Press Publ., 2016. 456 p. (In Russ.)

9. Belinskiy V. G. Polnoe sobranie sochineniy: $v 13$ tomakh [The Complete Works: in 13 Vols]. Moscow, Academy of sciences of the USSR Publ., 1955, vol. 6: Articles and Reviews. 1842-1843. 799 p. (In Russ.)

10. Belov S. V. Peterburg Dostoevskogo [Petersburg of Dostoevsky]. St. Petersburg, Aleteyya Publ., 2002. 372 p. (In Russ.)

11. Bocharov S. G. French Epigraph to "Eugene Onegin” (Onegin and Stavrogin). In: Moskovskiy pushkinist: ezhegodnyy sbornik [Moskovsky Pushkinist. Annual Collection]. Moscow, Nasledie Publ., 1995, issue 1, pp. 212-250. (In Russ.)

12. Vygotskiy L. S. Myshlenie i rech' [Thinking and Speech]. Moscow, Leningrad, Izdatel'stvo social'no-ekonomicheskoy literatury Publ., 1934. 323 p. (In Russ.)

13. Dostoevskaya A. G. Dnevnik 1867 goda [The Diary of 1867]. Moscow, Nauka Publ., 1993. 456 p. (In Russ.)

14. Evangelie Dostoevskogo: $v 2$ tomakh [The Gospel by Dostoevsky: in 2 Vols]. Moscow, Russkiy mir Publ., 2010, vol. 1: A Personal Copy of the New Testament Published in 1823 and Presented to F. M. Dostoevsky in Tobolsk in January 1850. 656 p. (In Russ.)

15. Iz arkhiva F. M. Dostoevskogo: «Idiot»: Neizdannye materialy [From the Archive of F. M. Dostoevsky: "Idiot": Unpublished Materials]. Moscow, Leningrad, Gosudarstvennoe izdatel'stvo khudozhestvennoy literatury Publ., 1931. 320 p. (In Russ.)

16. Iz arkhiva F. M. Dostoevskogo: "Prestuplenie i nakazanie»: Neizdannye materialy [From the Archive of F. M. Dostoevsky: "Crime and Punishment": Unpublished Materials]. Moscow, Leningrad, Gosudarstvennoe izdatel'stvo khudozhestvennoy literatury Publ., 1931. 219 p. (In Russ.)

17. Knizhnik-Vetrov I. V. A. V. Korvin-Krukovskaya (Zhaklar): drug F. M. Dostoevskogo, deyatel'nitsa Parizhskoy kommuny [A. V. Korvin-Krukovskaya (Jaclard): a Friend of F. M. Dostoevsky and an Activist of the Paris Commune]. Moscow, Vsesoyuznoe obshchestvo politkatorzhan i ssyl'nopereselentsev Publ., 1931. 116 p. (In Russ)

18. Lotman Yu. M. Inside the Thinking Worlds. In: Lotman Yu. M. Semiosfera [Lotman Yu. M. Semiosphere]. St. Petersburg, Iskusstvo-SPB Publ., 2000, pp. 150-390. (In Russ.)

19. Nazirov R. G. On the Question of the Prototype of Stavrogin. In: Nazirov R. G. O mifologii i literature, ili Preodolenie smerti: Stat'i i issledovaniya raznykh let [Nazirov R. G. On Mythology and Literature, or Overcoming Death: Articles and Studies of Different Years]. Ufa, 2010, pp. 297-308. (In Russ.)

20. Tikhomirov B. N. "A zhivu v dome Shilya...»: Adresa F. M. Dostoevskogo v Peterburge, izvestnye i neizvestnye. 1837-1881: issledovanie ["I Live in the House of Shil...". Addresses of F. M. Dostoevsky in St. Petersburg, The Known and Unknown. 1837-1881: Research]. St. Petersburg, Serebryanyy vek Publ., 2016. 151 p. (In Russ.) 
21. Tikhomirov B. N. Did Dostoevsky Have an Unrealized Intention Known as "The Usurer"? In: Neizvestnyy Dostoevskiy [The Unknown Dostoevsky], 2017, no. 3, pp. 3-15. Available at: http://unknown-dostoevsky.ru/files/redaktor_pdf/1508167445.pdf (accessed on May 15, 2018). (In Russ.)

22. Falikova N. E. American Motifs in the Late Novels of F. M. Dostoevsky. In: Novyye aspekty $v$ izuchenii Dostoevskogo [New Aspects in the Study of Dostoevsky]. Petrozavodsk, 1994, pp. 199-241. (In Russ.)

23. F. M. Dostoevskiy v vospominaniyakh sovremennikov: $v 2$ tomakh [F. M. Dostoevsky in the Memoirs of His Contemporaries: in 2 Vols]. Moscow, Khudozhestvennaya literatura Publ., 1990, vol. 1. 622 p. (In Russ.)

24. Efros A. M. Risunki poeta [Illustrations of the Poet]. Moscow, Academia Publ., 1933. 472 p. (In Russ.)

Received: August 15, 2018 